\title{
A model-data study of the 1999 St. Lawrence Island polynya in the Bering Sea
}

\author{
Haoguo $\mathrm{Hu},{ }^{1}$ Jia Wang, ${ }^{2}$ and Dao-Ru Wang ${ }^{3}$ \\ Received 19 May 2011; revised 14 September 2011; accepted 16 September 2011; published 14 December 2011.
}

[1] A Coupled Ice Ocean Model (CIOM) and in situ measurements were used to investigate sea ice and the St. Lawrence Island polynya (SLIP) in the Bering Sea in 1999. The modeled 1999 seasonal cycle of ice cover compared well with satellite measurements. The simulated maximum sea ice coverage was $\sim 0.8 \times 10^{6} \mathrm{~km}^{2}$, and the simulated maximum sea ice volume was $\sim 344 \mathrm{~km}^{3}$. The polynya south of St. Lawrence Island was captured by the CIOM and investigated in depth against the measurements. It was found that an offshore wind was necessary, but not sufficient on its own, for the development of the SLIP. It was found that a strong offshore wind, offshore surface water velocity, and the angle $\left(<60^{\circ}\right)$ between wind and water current are the three major factors for the development of the SLIP. Multiple-variable, linear regression models were developed to confirm these three mechanisms. Yearly potential sea ice production in the SLIP area was estimated to be about $95.7 \mathrm{~km}^{3}$, which accounts for $2.8 \%$ of the total potential production of $3393 \mathrm{~km}^{3}$ in the whole Bering Sea. Sea ice contributes to approximately $63 \%$ of winter salinity changes in the Bering Shelf $(<200 \mathrm{~m})$, while the SLIP can contribute more than twice the local salinity changes. The relationships among wind, sea ice, and surface ocean current were examined. The classic Ekman drift theory (that surface water velocity drifts $45^{\circ}$ to the right of the wind direction) is modified to be $50.4^{\circ}$ on the ice-covered Bering Shelf due to the year-round existence of a background northward ocean transport.

Citation: Hu, H., J. Wang, and D.-R. Wang (2011), A model-data study of the 1999 St. Lawrence Island polynya in the Bering Sea, J. Geophys. Res., 116, C12018, doi:10.1029/2011JC007309.

\section{Introduction}

[2] The Bering Sea is a subpolar, semienclosed sea (Figure 1), divided between deep basins and a broad continental shelf $(<200 \mathrm{~m})$. First-year ice with a thickness of $0.01-1.0 \mathrm{~m}$ forms in winter and covers approximately $75 \%$ of the northern shelf region. Maximum ice cover occurs in March or early April. The sea ice retreats in spring (April) and completely melts in summer (June). First-year ice is sensitive to synoptic weather changes and to large-scale climate changes such as the Pacific Decadal Oscillation, Arctic Oscillation, and El Niño-Southern Oscillation, which affect the regional oceanography and ecosystem.

[3] Polynyas are defined as the open water and thin ice that are surrounded by much thicker pack ice at locations where thick ice would be expected. They usually persist during the winter with intermittent openings and closings at the same location year after year. Coastal polynyas in the

\footnotetext{
${ }^{1}$ Cooperative Institute for Limnology and Ecosystems Research, School of Natural Resources and Environment, University of Michigan, Ann Arbor, Michigan, USA.

${ }^{2}$ NOAA Great Lakes Environmental Research Laboratory, Ann Arbor, Michigan, USA.

${ }^{3}$ Hainan Marine Development and Design Institute, Haikou, China.

Copyright 2011 by the American Geophysical Union. 0148-0227/11/2011JC007309
}

northern Bering Sea form as the predominant northerly winds advect sea ice southward away from the production coasts (or the ice factory). Major polynyas occur downwind of the Chukchi Peninsula, St. Lawrence Island, and the Seward Peninsula [Niebauer et al., 1999]. The St. Lawrence Island Polynya (SLIP) occurs frequently off the southern coast of the island under prevalent northerly winds. The SLIP outline has been observed from at least $235 \mathrm{~km}$ downwind [Niebauer, 1998]. The maximum ice speed in the SLIP may be greater than $30 \mathrm{~km} \mathrm{~d}^{-1}\left(0.35 \mathrm{~m} \mathrm{~s}^{-1}\right)$. Sea ice production is reported in the range of $10-12 \mathrm{~cm} \mathrm{~d}^{-1}$ in the SLIP [Cavalieri and Martin, 1994].

[4] Lynch et al. [1997] studied the SLIP using data from the European Space Agency ERS-1 synthetic aperture radar (SAR), Special Sensor Microwave Imager (SSM/I), advanced very high resolution radiometer (AVHRR), and an Arctic atmosphere-sea ice system model. The model captured the SLIP event during 24-27 February 1992 with moderate accuracy. They concluded that the polynya event was caused mainly by atmospheric forcing and that ocean surface currents have only a small impact.

[5] Drucker et al. [2003] examined the behavior of the SLIP in 1999 using a combination of AVHRR, RADARSAT SAR, meteorological data, in situ measurements derived from over-winter-moored upward looking sonar (ULS), and Sea-Bird salinity-temperature sensors. Sea ice thickness was 


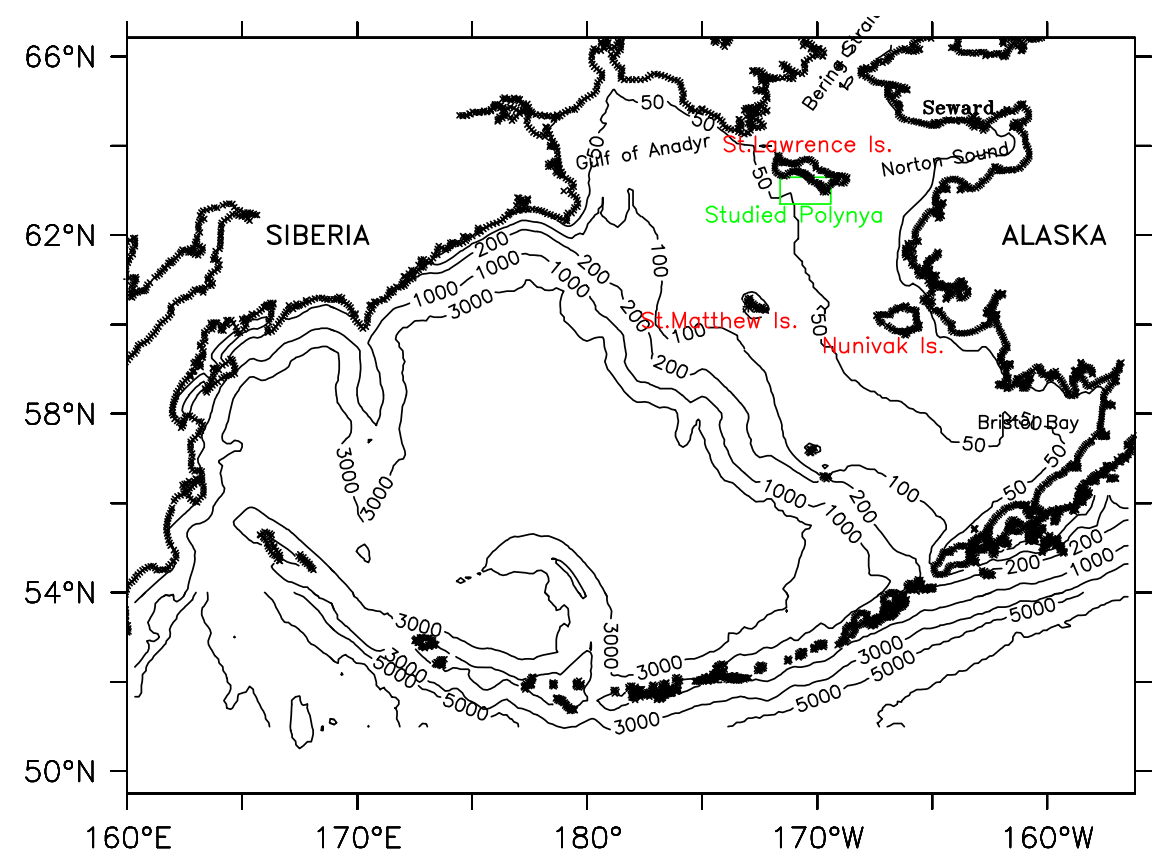

Figure 1. Bering Sea bathymetry (in $\mathrm{m}$ ) and model domain. The green rectangle indicates the St. Lawrence Island Polynya (SLIP) study area.

determined using AVHRR. Their results clearly show occurrence and timing of the SLIP, which motivated this modeling study.

[6] Danielson et al. [2006] investigated the role of polynyas in forming and disseminating saline water over the shelf using data from 14 moorings and oceanographic drifters that were deployed year-round south of St. Lawrence Island. The results show that horizontal and vertical advection of remote salinity to the SLIP region is more significant than the contribution of local sea ice formation, suggesting that the ocean circulation advection is an important factor in local salinity change.

[7] The formation of SLIP changes not only the hydrographic environment [Cavalieri and Martin, 1994; Danielson et al. 2006], but also the biological dynamics such as benthos [Grebmeier and Cooper, 1995]. Thus, it is necessary to study the controlling mechanisms of the polynya development and the hydrographic response to the SLIP. Motivated by the previous field studies, we use the Coupled Ice-Ocean Model (CIOM) [Wang et al., 2002, 2005, 2009] driven by high-frequency (6-hourly) atmospheric forcing to systematically investigate the mechanisms of SLIP formation and its association with the magnitude and direction of winds and surface currents. The contribution to salinity change by local sea ice formation and remote advection was also investigated.

[8] This paper is organized as follows. Section 2 describes the model configuration. Model results are given in section 3 . We discuss in detail the simulated sea ice freezing and melting processes (section 3.1) and the response of sea ice flow and surface current to wind forcing (section 3.2). Then, we identify factors controlling the SLIP development, which are confirmed quantitatively by multiple-variable, linear regression models (section 3.3). We further investigate the temporal and spatial distributions of sea ice thickness, temperature, and salinity in the SLIP (sections 3.4 and 3.5) and potential sea ice production and its contribution to salinity (section 3.6). Conclusions are given in section 4.

\section{Descriptions of the CIOM}

[9] The detailed description of the CIOM development given by Yao et al. [2000] and Wang et al. [2002, 2005]. The CIOM was successfully applied to the Labrador Sea [Yao et al., 2000; Tang, 2008], the Pan-Arctic Ocean [Wang et al., 2004, 2005; Wu et al., 2004; Long et al., 2011], the Beaufort Sea [Wang et al., 2003, 2008], and the Bering Sea [Wang et al., 2009; Hu and Wang, 2010]. The ocean model used is the Princeton Ocean Model (POM) [Blumberg and Mellor, 1987; Mellor, 2004], and the ice model used is a full thermodynamic and dynamics model [Hibler, 1979, 1980] that prognostically simulates sea ice thickness, sea ice concentration, ice velocity, and heat and salt fluxes through sea ice into the ocean. The ice model has full thermodynamics with one-layer ice and full dynamics with viscousplastic rheology [Hibler, 1979, 1980; Wang et al., 1994]. A multiple-thickness category ice model [Thorndike et al., 1975; Hibler, 1980] was used, fully coupled to the ocean model [Mellor and Kantha, 1989]. In this study, there are 10 ice categories $h_{i}(i=1 \ldots 10), 0.0,0.2,0.4,0.6,0.9,1.2$, $1.6,2.0,2.5$, and $3.2 \mathrm{~m}$; each category has a percentage or concentration $c_{i}$ in a grid point, and $\sum_{i=1}^{10} c_{i}=100$. The weighted average ice thickness of each grid is defined as: $\sum_{i=1}^{10} c_{i} \times h_{i}$. Ice thickness of less than $12 \mathrm{~cm}$ is defined as a polynya event. The thermodynamics between the ice-water interface such as bottom-lateral melting is described in the appendix.

[10] The model configuration is the same as that of Wang et al. [2009] and $H u$ and Wang [2010], and is briefly 


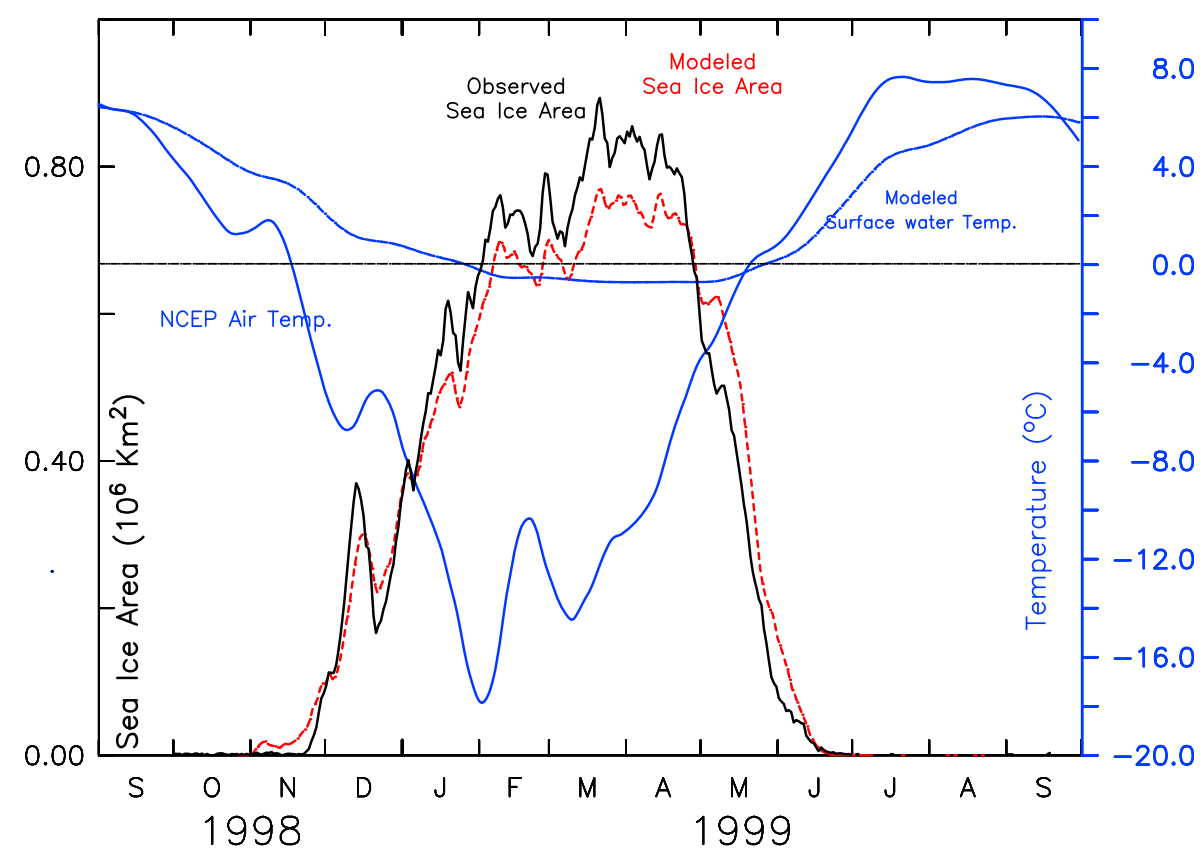

Figure 2. Seasonal variations of observed sea ice cover (black solid line, $\times 10^{6} \mathrm{~km}^{2}$ ), simulated sea ice cover (red dotted line, $\times 10^{6} \mathrm{~km}^{2}$ ), modeled sea surface temperature (blue dashed line), and observed sea surface air temperature (blue solid line). All variables are averaged over the whole Bering Shelf $(<200 \mathrm{~m})$.

introduced here. The Bering-CIOM was configured in horizontal spherical grids with $1 / 6^{\circ}$ longitude $(\sim 7.4 \mathrm{~km}$ in the Bering Strait and $\sim 10 \mathrm{~km}$ near the Aleutian Islands) and $1 / 12^{\circ}$ latitude $(\sim 9.2 \mathrm{~km})$ covering the whole Bering Sea. There are 24 sigma levels for the ocean model in the vertical (at $\sigma=0,-0.008,-0.016,-0.031,-0.063,-0.125,-0.188$, $-0.250,-0.313,-0.375,-0.438,-0.500,-0.563,-0.625$, $-0.688,-0.750,-0.813,-0.875,-0.938,-0.969,-0.984$, $-0.992,-0.996,-1$; here $\sigma=\frac{z^{-} \eta}{H+\eta}$, where $z$ is vertical coordinate and negative downward, $\eta$ is the mean water elevation, and $H$ is the water depth.). The vertical resolution is higher near the surface and the bottom for a better representation of the surface and bottom boundary layers. A parameterization of wind-wave mixing is introduced following $H u$ and Wang [2010]. The open boundaries (velocity, temperature, and salinity) are embedded by a global climate (atmosphere-ice-ocean-land) model with a resolution of $1 / 6^{\circ} \times 1 / 4^{\circ}$ (about $25 \mathrm{~km}$ ) [Watanabe et al., 2006 with a volume transport conservation principle and a radiation property [Wang et al., 2001].

[11] The model was initialized with climatologic temperature and salinity data from the Polar Science Center Hydrographic Climatology (PHC 3.0) [Steele et al., 2001]. The National Centers for Environmental Prediction (NCEP) reanalysis data consisting of 6-hourly measurements of wind, air temperature, shortwave radiation, precipitation, humidity, and sea level pressure were used to drive the model. The NCEP reanalysis data sets are created by assimilating climate observations into a climate model throughout the entire reanalysis period in order to obtain observation-constrained model results. Observations are from many different data sources including ship, satellite, ground station, radiosonde observation (RAOBS), and radar measurements. The NCEP reanalysis products are widely used in the community.
[12] The sea ice velocity, concentration, and thickness were set to zero as initial conditions. The model is considered at an equilibrium state if $E_{n}-E_{n-1}<5 \% E_{n}$, where $E_{n-1}$ is the previous year's kinetic energy. After a 4-year spin-up using 1998 forcing, a dynamic and thermodynamic seasonal cycle was established. Then, the model was run for years 1998-1999 with 6-hourly atmospheric forcing using the previous 4-year output as the initial conditions.

[13] To measure the CIOM's skill in reproducing the measurements, a statistical measure of skill is introduced to conduct the model-data comparison. Mean bias deviation (MBD) is defined as

$$
\mathrm{MBD}=100 \frac{\frac{1}{N} \sum_{i=1}^{N}\left|x_{i}-y_{i}\right|}{\frac{1}{N} \sum_{i=1}^{N} y_{i}},
$$

where $x_{i}$ and $y_{i}(i=1,2,3, \ldots, N)$ are the modeled and measured time series of any variable such as ice area, sea surface temperature (SST) and $N$ is the total sampling number. MBD measures the error of model output (in \%) relative to the observed data.

\section{Results}

\subsection{Simulation of Sea Ice in the 1998-1999 Ice Season}

\subsubsection{Freezing Process}

[14] As solar radiation gradually diminished in September, surface air temperature (SAT) over the Bering Shelf began to cool down (Figure 2). The areal averaged SAT fell below the freezing point in November. However, because of the water's large heat capacity, the simulated SST (areal average 

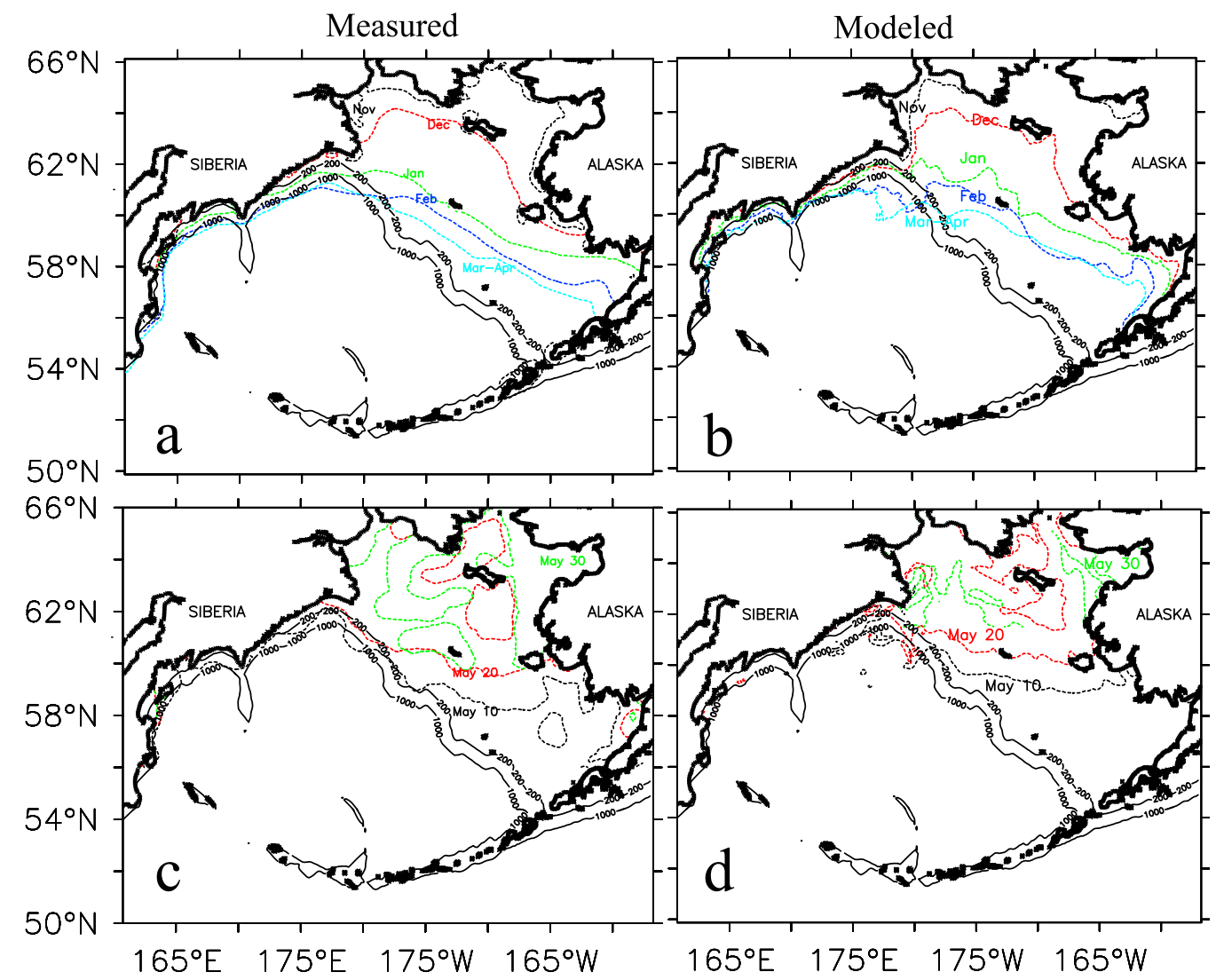

Figure 3. Sea ice edge. (a) Sea ice extent from Nimbus-7 SMMR and DMSP SSM/I passive microwave data from November 1998 to April 1999 and (b) model ice extent from November 1998 to April 1999 (November is indicated in black, December in red, January in green, February in blue, and March-April in light blue). (c) Satellite data in May 1999 and (d) model result in May 1999 (10 May is indicated in black, 20 May in red, and 30 May in green).

on the Bering Shelf $<200 \mathrm{~m}$ ) slowly decreased with a lag of about 2 months compared with the SAT.

[15] Sea ice began to form in the northern Bering Sea in early November when the saltwater reached the freezing point. Although the air temperature in the northern Bering Shelf was far below zero (the minimum reaches $-20^{\circ} \mathrm{C}$ ), sea ice formed only along the coast of the Gulf of Anadyr and the western Bering Strait (see Figures $3 a$ and $3 b$ ). As the SAT decreased, sea ice cover gradually increased. In midDecember, the sea ice edge appeared around St. Lawrence Island and near the Alaskan coast and continued to extend southward in January and February. At the end of March and early April, the sea ice edge reached its southernmost point, where it melted in the relatively warm water because of bottom-lateral melting. The modeled maximum sea ice coverage of $\sim 8 \times 10^{5} \mathrm{~km}^{2}$ is $11 \%$ less than the satellite measurements of $\sim 9 \times 10^{5} \mathrm{~km}^{2}$ (Figure 2). The simulated maximum sea ice volume is $344 \mathrm{~km}^{3}$.

[16] The relationship of sea ice thickness and concentration is examined using a thickness-concentration diagram (Figure 4). In November, there were only a few grid cells that indicated that sea ice formed only in small areas. The maximum sea ice thickness was only $20 \mathrm{~cm}$ (Figure 4a). From December to January (Figures $4 b$ and $4 c$ ), an increase of grid cells indicates an increase of ice-covered area. Although the number of grid cells did not increase from
January to February (Figure 4d) (also see the ice edge in Figures $3 \mathrm{a}$ and $3 \mathrm{~b}$ ), sea ice concentration and thickness increased noticeably. The maximum thickness was greater than $1.2 \mathrm{~m}$, and the sea ice cover had extended to its farthest point, where it melted over the warmer water. However, because the air temperature was still very low $\left(<-20^{\circ} \mathrm{C}\right)$ and the ice-covered water remained at the freezing point, sea ice concentration and thickness continued to increase.

\subsubsection{Melting Process}

[17] The SAT began to rise in mid-March (Figure 2). However, the SST continued to decrease, because the SAT was still lower than the SST. Sea ice coverage continuously increased, and so did ice thickness until early April. Sea ice remained relatively steady from the end of March to midApril in terms of both thickness and coverage.

[18] From 15 March (Figure 4e) to 15 April (Figure 4f), although the total modeled volume slightly increased, the grid cells with high concentration and low thickness decreased, while the grid cells with low concentration and high thickness increased. This indicates that sea ice ridging occurred and dominated the sea ice redistribution.

[19] Average SAT quickly increased to above $0^{\circ}$ at the end of May, while the SST slowly increased because of the slowly disappearing sea ice cover. The sea ice melted quickly in May (Figures 4g, 4h, and 4i) compared with its slow formation from November to April. On 10 May, the sea 


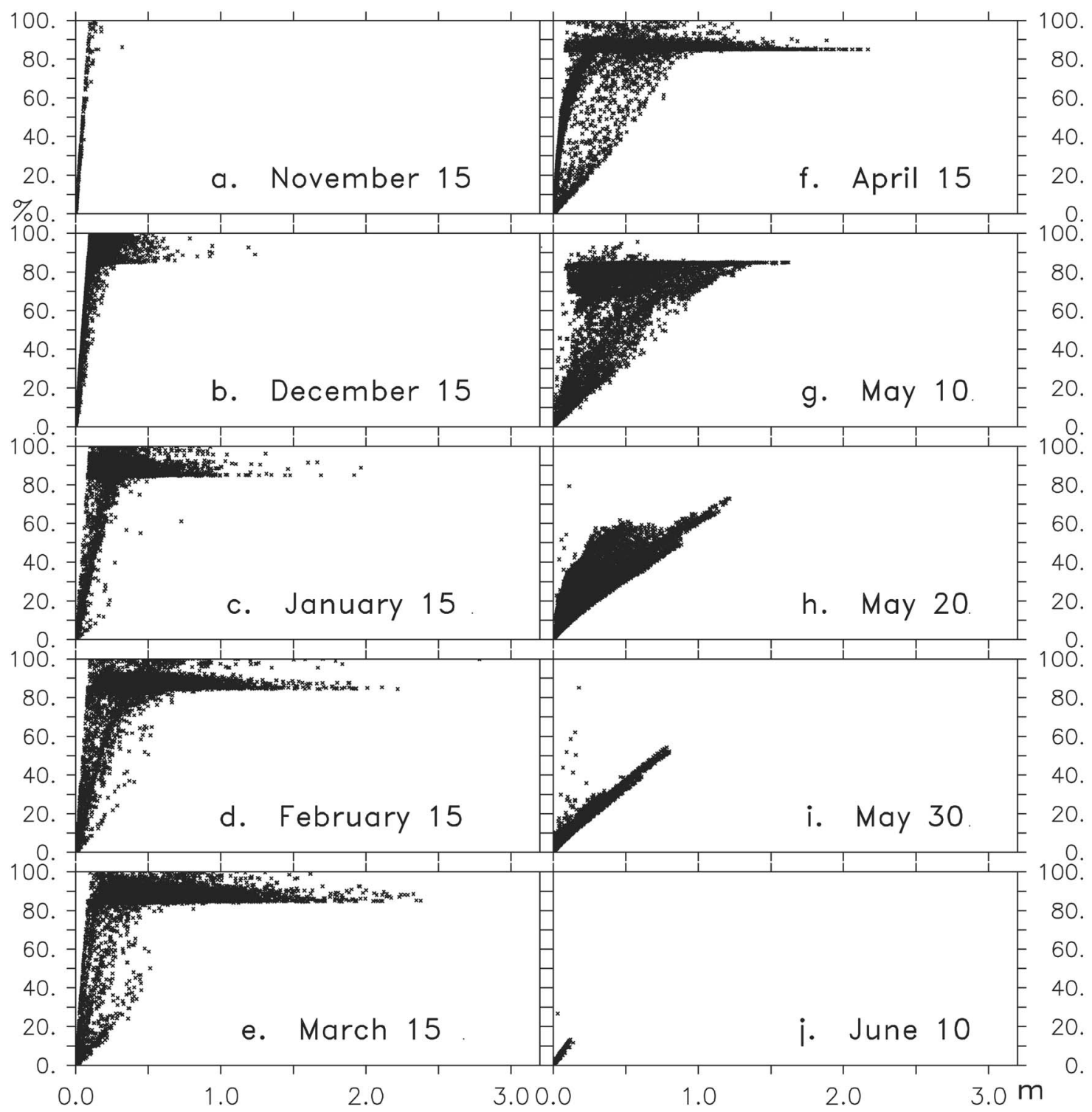

Figure 4. Simulated sea ice thickness-concentration diagram in the Bering Sea. The horizontal coordinate indicates thickness (in $\mathrm{m}$ ), and the vertical coordinate indicates concentration (in \%). The dots represent all the model ice-covered grid cells.

ice edge remained in the area of the 100-200 $\mathrm{m}$ isobaths, and it retreated quickly from the Alaskan coast by 20 May. At the end of May, sea ice existed in the Gulf of Anadyr, and scattered ice was seen in the western Bering Shelf. The number of grid cells with ice cover were significantly reduced, which indicates a rapidly melting ice cover, and the grid cells shift to the low-concentration and low-thickness category. In June (Figure 4j), only the northern Bering Shelf near the Bering Strait had scattered, thin, low-concentration sea ice.

\subsection{Response of Sea Ice and Surface Current Velocity to Wind Forcing}

[20] Observations show that ice drift rates vary from 17 to $22 \mathrm{~km} \mathrm{~d}^{-1}\left(0.2-0.25 \mathrm{~m} \mathrm{~s}^{-1}\right)$ to as fast as $28-32 \mathrm{~km} \mathrm{~d}^{-1}$ $\left(0.32-0.37 \mathrm{~m} \mathrm{~s}^{-1}\right)$ in the Bering Sea Shelf [Shapiro and Burns, 1975; Muench and Ahlnas, 1976; Weeks and
Weller, 1984; Niebauer et al., 1999]. In the Bering Strait, sea ice velocity as fast as $50 \mathrm{~km} \mathrm{~d}^{-1}\left(0.58 \mathrm{~m} \mathrm{~s}^{-1}\right)$ was observed, although there were some reversals in direction that were due to changes in wind direction [Pease, 1980]. Ice thickness is $0.5-1.0 \mathrm{~m}$ in the Bering Sea, and rafting does occur [Niebauer et al., 1999]. A chart of wind vector, modeled surface current, and ice velocity (averaged from January to April, Figure 5) shows that the sea ice velocity was high $\left(\sim 0.2 \mathrm{~m} \mathrm{~s}^{-1}\right)$ in the western and low $\left(\sim 0.1 \mathrm{~m} \mathrm{~s}^{-1}\right)$ in the eastern Bering Shelf.

[21] Sea ice moves largely in response to local winds and ocean currents. An old rule of thumb, based on the classical Ekman theory, is that water moves with a speed of about $2 \%$ of the surface wind and about $45^{\circ}$ to the right of the wind. Thorndike and Colony [1982] studied Arctic sea ice motion in response to geostrophic winds that are derived from a sea level pressure field using geostrophic calculation. 


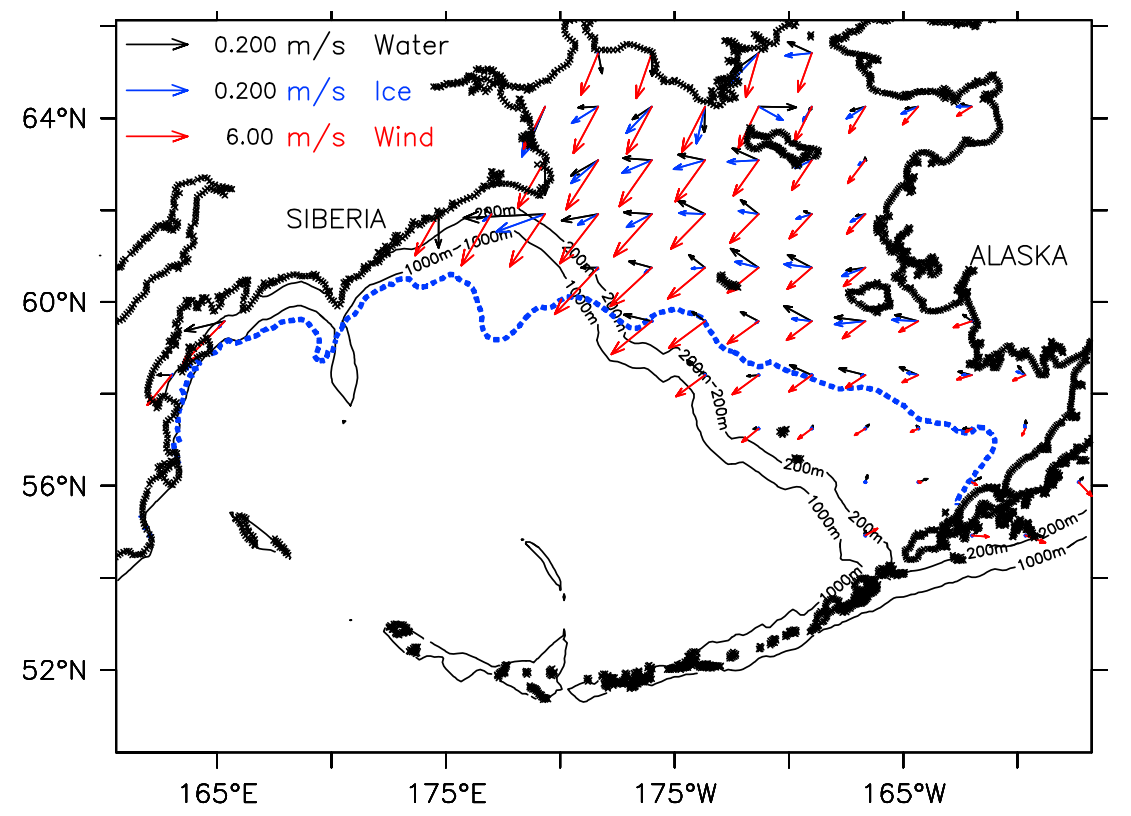

Figure 5. Time mean chart of wind, ice, and surface current vectors averaged from January to April. The vectors are drawn every 14 grids in both longitude and latitude. Wind velocity (NCEP data) is in red, simulated ice velocity in blue, and simulated water velocity in black. The blue dotted line indicates the simulated maximum sea ice edge.

They found that only about half of the long-term (several months) average ice motion is directly related to the wind, and the other half is due to the mean ocean circulation. Summer Arctic sea ice moves at about $18^{\circ}$ to the right of the wind at 0.008 times the wind speed, i.e., sea ice speed is only $0.8 \%$ of the geostrophic wind speed.

[22] To investigate the wind-driven polynya in the vicinity of the St. Lawrence Island area, it is necessary to understand the relationships between the wind, sea ice, and surface currents on the Bering Shelf using the model simulations. The angles among the vectors vary from location to location (Figure 5). The mean ice velocity, wind, and surface current averaged both over the ice-covered area (in space) and from December to April (in time) have the following relation (also see Figure 6a):

$$
\begin{gathered}
\vec{V}_{\text {ice }}=0.0189 \vec{V}_{\text {wind }} e^{-i\left(32.7^{\circ}\right)}=0.0189 \vec{V}_{\text {wind }} e^{-i 0.57}, \\
\vec{V}_{\text {water }}=0.91 \vec{V}_{\text {ice }} e^{-i\left(17.7^{\circ}\right)}=0.91 \vec{V}_{\text {ice }} e^{-i 0.31} .
\end{gathered}
$$

[23] The predominant northeasterly wind on the Bering Shelf blows the sea ice toward the west or southwest. The wind, ice, and water velocities have a basic relationship in which a polynya is more likely to occur under a prevailing northerly wind, since ice flow is steered to the right of the wind direction (at $\sim 33^{\circ}$ ). The surface water moves to the right of the wind direction at $50.4^{\circ}$, larger than the commonly used $45^{\circ}$ based on the classic Ekman drift theory in deep seas. The reason is that the surface velocity is the summation of the surface Ekman (friction) velocity and a background velocity. According to the Ekman theory (Figure 6b) [Pedlosky, 1987, equation 4.10.12],

$$
\vec{u}_{E}=\vec{u}-\vec{u}_{0}=\frac{a}{2}(\vec{\tau}-\vec{k} \times \vec{\tau})
$$

then we have

$$
\vec{u}=\vec{u}_{0}+\vec{u}_{E}=\vec{u}_{0}+\frac{a}{2}(\vec{\tau}-\vec{k} \times \vec{\tau}),
$$

where $\vec{u}$ is the surface velocity, $\vec{u}_{E}$ is the surface Ekman (friction) velocity, $\vec{u}_{0}$ is the background velocity, $a$ is a coefficient, $\vec{\tau}$ is the wind stress, and $\vec{k}$ stands for vertical direction.

[24] Since there is a constant northwestward vertically averaged current year-round that is due to the Pacific-Arctic pressure head [Woodgate et al., 2005], which leads to a Bering Strait inflow to the Chukchi Sea at an average annual rate of $0.8 \mathrm{~Sv}$ [Wang et al., 2009; Hu and Wang, 2010], the wind-water angle (WWA) between the wind and the surface current is larger than $45^{\circ}$ (Figure 6a). To confirm the existence of a northwestward current (mean flow) in the northern Bering Shelf, a no-wind-forcing experiment was conducted to derive the depth-average ocean current field on the shelf (not shown). It was found that there is a systematic northward flow or transport on the Bering Shelf that acts as the background flow that distorts or modifies the classic Ekman drift theory on the ice-covered Bering Shelf. The ratio of the magnitudes of wind, ice, and water velocity is 100:1.9:1.7, which is consistent with the $2 \%$ rule of thumb.

\subsection{Factors Controlling the SLIP Development}

[25] Drucker et al. [2003] and Danielson et al. [2006] measured six polynya events in 1999. The polynyas were identified as frazil polynyas (FPs) and congelation polynyas (CPs), occurring on 7-14 January (FP1), 1-7 February (CP1), 13-15 February (FP2), 21-24 February (FP3), 18-20 March (FP4), and 25-29 March (FP5). An FP is a spongy or slushy accumulation of frazil ice in a body of water, while a CP is congealed ice that forms under existing ice cover. Drucker 
a

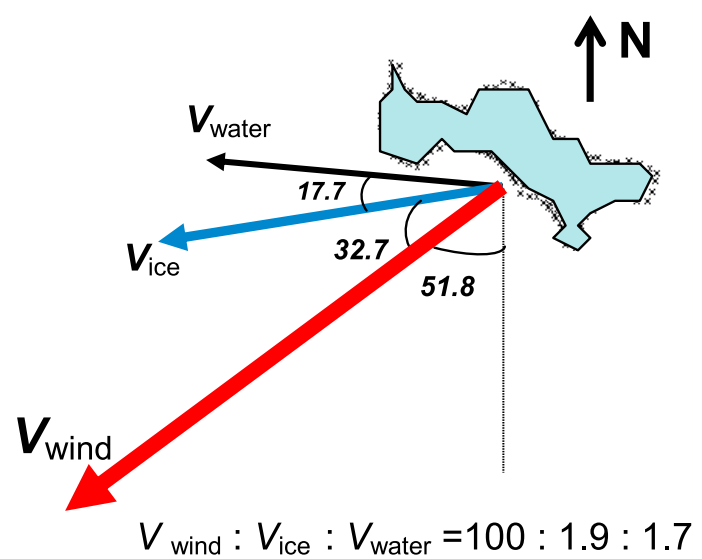

b

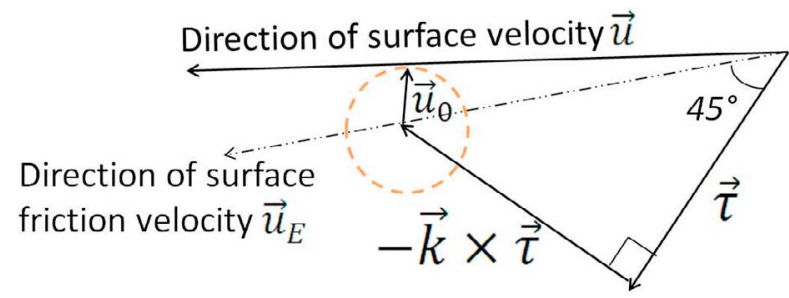

Figure 6. (a) The relations among the wind, ice, and surface current on the Bering Shelf (spatial-averaged) in winter (JFMA averaged) 1999, where wind is from NCEP data, and ice and current are from model result. (b) The relation between wind stress and surface velocity based on the Ekman drift theory, $\mathbf{u}_{E}=\mathbf{u}-\mathbf{u}_{0}=a / 2(\boldsymbol{\tau}-\mathbf{k} \times \boldsymbol{\tau})$ [Pedlosky, 1987, equation 4.10.12, p. 229], where $\mathbf{u}$ is the surface velocity, $\mathbf{u}_{E}$ is the surface Ekman (friction) velocity, $\mathbf{u}_{0}$ is the background velocity, $a$ is a coefficient, $\boldsymbol{\tau}$ is the wind stress, and $\mathbf{k}$ stands for vertical direction.

et al. also pointed out that suitable satellite imagery was lacking for April. Since northerly winds exceeded $10 \mathrm{~m} \mathrm{~s}^{-1}$ on 1, 4-5, 8-9, 11-12, 16-20, and 29 April, and the SAT was generally below $-10^{\circ} \mathrm{C}$, polynyas were likely present in April (also see Figure 7) [Danielson et al., 2006]. The four major observed polynya events, FP1, CP1, FP4, and FP5, were captured by the present model (Figure 8f), which showed that the average (maximum) polynya area can reach $0.6(0.93) \times 10^{3} \mathrm{~km}^{2}, 1.0(1.25) \times 10^{3} \mathrm{~km}^{2}, 0.68(1.33) \times$ $10^{3} \mathrm{~km}^{2}$, and $1.93(2.74) \times 10^{3} \mathrm{~km}^{2}$, respectively. Note that the SLIP is a latent heat polynya, rather than a sensible heat polynya, since it forms in an area where sea ice is removed from the region as quickly as it forms by winds and/or ocean currents. Given their high rates of sea ice formation, these types of polynya are often called "ice factories." In contrast, sensible heat polynyas form during an upwelling of warm water, which melts existing ice and/or prevents new ice from forming. These are areas of low ice production.

[26] An offshore wind is considered to be the primary forcing mechanism for polynya development. Winds were predominantly northerly in the SLIP area from January to April 1999 (Figure 8a). The wind speed ranged from 1 to
$16 \mathrm{~m} \mathrm{~s}^{-1}$ with occasional southerly winds. The air temperatures (NCEP data) were from $-20^{\circ} \mathrm{C}$ to $-40^{\circ} \mathrm{C}$.

[27] Although under a prevailing northerly wind for almost the whole winter, the polynya occurred only intermittently. This indicates that the offshore wind speed is a necessary, but may not be a sufficient, condition to trigger a polynya event. Other factors that trigger polynya formation in addition to wind speed include wind duration and current velocity.

[28] Mean northerly wind speeds varied in polynya events (Figure 8a): $10.6 \mathrm{~m} \mathrm{~s}^{-1}$ in FP1, $4 \mathrm{~m} \mathrm{~s}^{-1}$ in CP1, $8.5 \mathrm{~m} \mathrm{~s}^{-1}$ in FP4, and $8 \mathrm{~m} \mathrm{~s}^{-1}$ in FP5. During 7-14 February (CP1), although the mean speed of $4 \mathrm{~m} \mathrm{~s}^{-1}$ was even weaker than the January-April average speed of $6.4 \mathrm{~m} \mathrm{~s}^{-1}$, a large polynya event did occur. This indicates that during low offshore wind conditions, a polynya may occur, implicating the surface ocean current as a possible cause. The duration of the offshore winds (Table 1) ranged from 2 to 8 days, with an average of $\sim 6$ days, while the small FP2 and FP3 events were 2 and 3 days, respectively, which were much lower than the average. This implied that the shorter the wind duration, the smaller the SLIP.

[29] Sea ice movement depends not only on wind stress, but also on water drag. Using observed surface currents would be ideal for this analysis. However, only 1-year near-bottom mooring data were available in this area, and the surface moorings for measuring water velocity were impossible in such a dynamic ice-covered sea. The mooring stations are $\mathrm{P}_{1}, \mathrm{P}_{2}$, and $\mathrm{F}_{3-8}$ (see Figure 7 for locations). When comparing the observed bottom velocity (Figure $8 \mathrm{~b}$ ) with the modeled bottom velocity (Figure 8c), it shows that the bottom currents are reasonably reproduced. Therefore, we used the modeled surface current (Figure 8d) for this study. The surface water velocity and sea ice velocity have a magnitude of $0-0.2 \mathrm{~m} \mathrm{~s}^{-1}$ (Figures $8 \mathrm{~d}$ and $8 \mathrm{e}$ ), which is about $1.5-2$ times larger than the bottom current $\left(0-0.1 \mathrm{~m} \mathrm{~s}^{-1}\right)$ with a clockwise inclination.

[30] When comparing the wind vectors (Figure 8a) with the surface water currents (Figure $8 \mathrm{~d}$ ), and based on the previous studied wind-driven ice motion [Thorndike and Colony, 1982], it is reasonable to examine the effect of surface water currents on the polynya development. Therefore, we used the wind-water angle (WWA) to evaluate the impacts of both the wind and current on the SLIP development. We used the WWA (the angle between wind and water velocity vectors) to evaluate the impacts of both the wind and current on the SLIP development. The WWA (Figure 8e) offers a reasonable explanation for the SLIP development. The polynya events occurred mostly when the angle between wind and water flow directions were less than $60^{\circ}$ (Figure 8g), except for two small events, FP2 and FP3. During FP2 and FP3, although the offshore wind conditions were favorable to the development of the SLIP, the surface ocean currents flowed northwestward, thus against the wind direction. Nevertheless, the polynyas were reported. This indicates that high offshore wind stress can overwhelm water stress, triggering a small polynya. However, the model did not capture these two small events using the established polynya thickness criterion of $12 \mathrm{~cm}$.

[31] To investigate why the model did not capture the FP2 and FP3 polynyas, which might be due to the shorter 


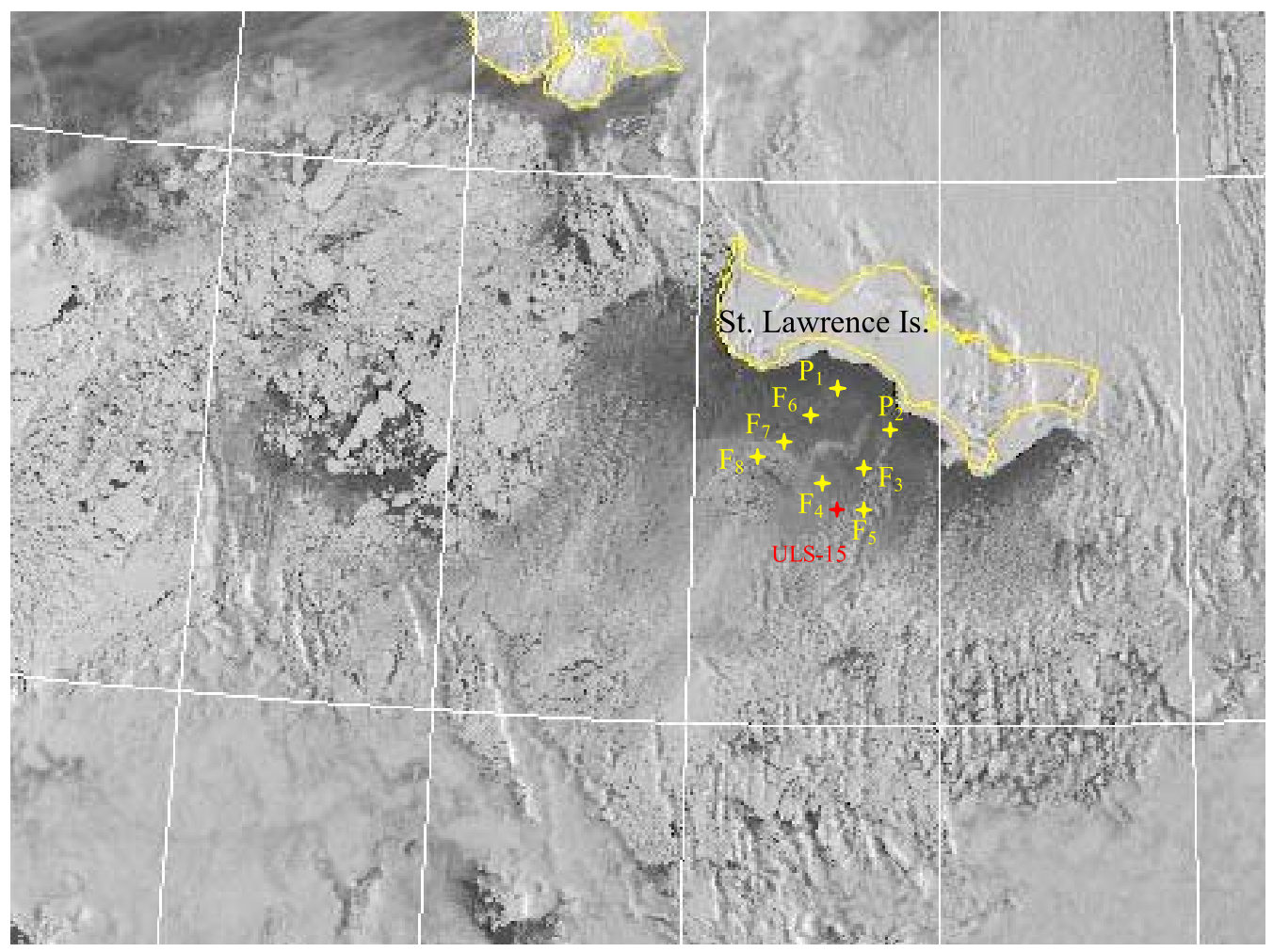

Figure 7. Sea ice distribution from satellite measurement on 14 April 2007. Data from Bering Sea Ecosystem Study projects: http://www.eol.ucar.edu/projects/best/satellite.shtml. $\mathrm{P}_{1-2}$ and $\mathrm{F}_{3-8}$ are mooring stations in red, and the location of the Upward Looking Sonar (ULS-15) is in yellow. A dark color indicates lower reflectivity, i.e., thin ice with a low albedo; A gray or white color indicates a solid ice cover.

duration of the northerly winds (Table 1 ), we conducted an experiment that extended the duration of the northerly wind following the FP3 event for another 10 days, with other conditions identical to those in the standard run. It was found that although the fixed northerly wind was extended for another 10 days, the FP3 did not occur (not shown) because there existed a northward surface ocean current during this period. Again, this further confirms that the surface ocean current is an important factor in triggering SLIP.

[32] To summarize the mechanisms that may be responsible for the SLIP development, Table 1 lists all the possible factors examined above. An important finding is that when both the surface winds and surface ocean currents are consistently in the downwind direction with a small WWA $\left(<60^{\circ}\right)$, a polynya can be triggered. This indicates that the surface ocean current is as important as the surface wind. Other factors such as offshore wind duration may be important if the surface ocean current is favorable ( or WWA $<60^{\circ}$ ).

[33] To express the possible mechanisms discussed above in a quantitative form, multiple-variable linear regression models were developed in the following form, following Wang et al. [1997] and X. Bai et al. (Interannual variability of Great Lakes ice cover and its relationship to NAO and ENSO, submitted to Journal of Geophysical Research, 2011):

$$
\begin{aligned}
\text { Area }_{\text {SLIP }}= & a_{0}+a_{1} \mathrm{WWA}+a_{2} \tau_{x_{-} \text {water }}+a_{3} \tau_{y_{-} \text {water }} \\
& +a_{4} \tau_{x_{-} \text {wind }}+a_{5} \tau_{y_{-} \text {wind }}
\end{aligned}
$$

where $\tau$ is the wind and water stress (in $\left.\mathrm{N} \mathrm{m}^{2}\right)$ and $a_{i}(i=$ $0 \ldots 5)$ are the regression coefficients. We conducted experiments with all the combinations and discuss here only the first three models that have the best hindcast skills based on their adjusted $R^{2}$ values (Table 2). Table 2 lists all the individual regression coefficients and their statistical properties (third-eighth columns), as well as the overall statistical properties (ninth-twelfth columns). The $T$ value measures the significance level for individual coefficients; thus the larger the $T$ value, the better the coefficient. The smaller the probability value, the better the coefficient. For example, 0.106 stands for the $89.4 \%$ significance level. The smaller the standard error, the more significant the coefficient (factor) is in the model.

[34] Model 1 includes all the terms in equation (2); model 2 includes only three terms, WWA and the southnorth components of wind and water stresses; and model 3 is the same as model 1, but without the WWA. It is found that model 2 possesses the highest adjusted $R^{2}$ value of 0.17 at the $99 \%$ significance level, while models 1 and 3 have adjusted $R^{2}$ values of 0.143 and 0.110 , respectively, at the $96.4 \%$ and $94.6 \%$ significance levels, respectively. Model 2 has the highest F statistics, because it captures the three key mechanisms responsible for the development of the SLIP, as discussed above. It is also interesting to note that model 3 is not as accurate as model 1 because the WWA is excluded in model 3. This indicates that the WWA is a significant factor for the development of the SLIP. 

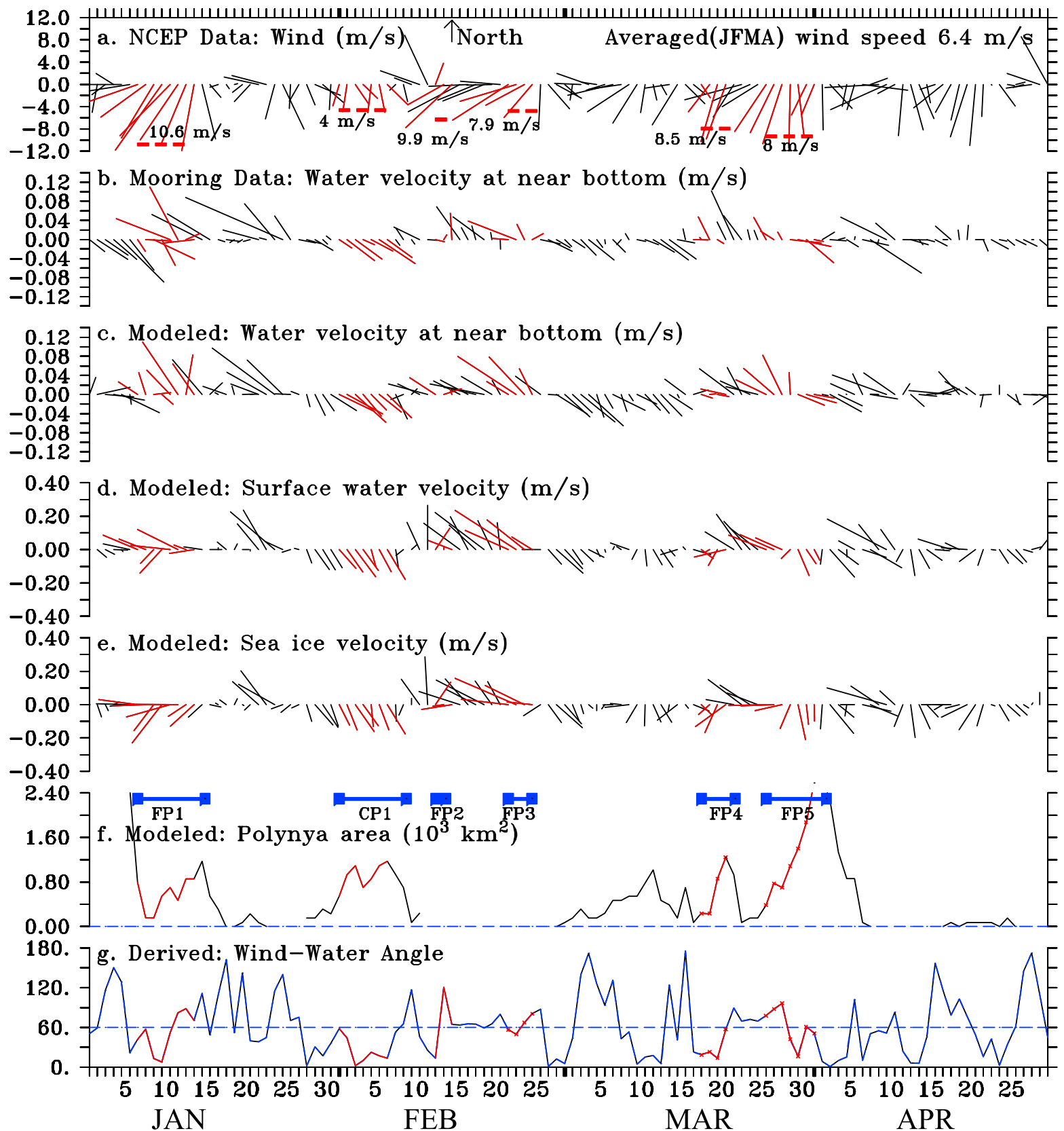

Figure 8. The 1999 time series of (a) wind velocity (data); the mean northerly speeds of the six major polynya events are shown as $-10.6,-4,-9.9,-7.9,-8.8$, and $-8 \mathrm{~m} \mathrm{~s}^{-1}$, respectively. The mean speed is $6.4 \mathrm{~m} \mathrm{~s}^{-1}$ for January-April 1999. (b) Averaged moored water velocity near bottom; the selected stations in the studied polynya area are $\mathrm{P}_{1}, \mathrm{P}_{2}, \mathrm{~F}_{3}, \mathrm{~F}_{4}, \mathrm{~F}_{5}$, and $\mathrm{F}_{8}$ (see Figure 7 for locations; note that $\mathrm{F}_{6}$ and $\mathrm{F}_{7}$ were not used since only salinity and temperature were measured at these two stations). (c) Modeled water velocity near bottom $\left(\mathrm{m} \mathrm{s}^{-1}\right)$, (d) modeled surface water velocity $\left(\mathrm{m} \mathrm{s}^{-1}\right)$, (e) modeled sea ice velocity $\left(\mathrm{m} \mathrm{s}^{-1}\right.$ ), and (f) modeled polynya area (in units of $10^{3} \mathrm{~km}^{2}$ ). FP indicates observed frazil polynya, and CP indicates observed congelation polynya, which is defined by Drucker et al. [2003]; and (g) modeled WWA (see text for details). The periods of six polynya events are marked in red.

\subsection{Temporal Distribution of Sea Ice Thickness, Temperature, and Salinity in the SLIP}

[35] Sea ice thickness at the polynya edge (ULS-15; see Figure 7 for location) was measured with an upward looking sonar [Drucker et al., 2003] and was reproduced by the model (Figure 9). The average ice thickness was $0.3-0.4 \mathrm{~m}$ from 26 January to 10 February 1999 that covered the major polynya event, CP1. On 26 January, ice thickness was $\sim 0.8 \mathrm{~m}$ and reduced to $\sim 0.5 \mathrm{~m}$ on 27 January. Ice thickness continued to reduce to $\sim 0.4 \mathrm{~m}$ on 30 January. After that, the thickness remained at $0.3-0.4 \mathrm{~m}$. Our model simulated the ice thickness variation well throughout the same period. 
Table 1. SLIP Occurrence and Possible Factors Responsible for SLIP Development

\begin{tabular}{|c|c|c|c|c|c|c|}
\hline Factors/SLIP Event & FP1 & $\mathrm{CP} 1$ & FP2 & FP3 & FP4 & FP5 \\
\hline Downwind direction & Yes & Yes & Yes & Yes & Yes & Yes \\
\hline Mean wind speed ${ }^{\mathrm{a}}\left(\mathrm{m} \mathrm{s}^{-1}\right)$ & -10.6 & -4 & -9.9 & -7.9 & -8.5 & -8 \\
\hline Modeled downwind duration (days) & 8 & 8 & 2 & 3 & 6 & 8 \\
\hline Modeled downwind current & Yes & Yes & No & No & Yes & Yes \\
\hline Modeled average WWA (deg) & 49 & 19 & 69 & 61 & 22 & 35 \\
\hline Modeled average SLIP $\operatorname{area}^{\mathrm{b}}\left(10^{3} \mathrm{~km}^{2}\right)$ & 0.52 & 0.92 & 0 & 0 & 0.61 & 1.82 \\
\hline
\end{tabular}

${ }^{\mathrm{a}}$ Negative means toward south.

${ }^{\mathrm{b}}$ With thickness $<12 \mathrm{~cm}$.

[36] Hourly measured temperature and salinity south of St. Lawrence Island (see Figure 7 for mooring locations of $\mathrm{P}_{1-2}$ and $F_{3-8}$ ) are shown in Figure 10 (solid lines). From January to April, salinity had an upward trend and increased in the four major polynya events, FP1, CP1, FP4, and FP5, while salinity decreased in the minor events of FP2 and FP3. This was due to low-salinity water that was advected from the south by the northwestward ocean currents (see Figure 11a). The simulated salinity with a mean of 33.24 practical salinity units (psu) (dashed line in Figure 10a) is higher than the observed salinity with a mean of 32.93 psu. The mean bias deviation (MBD) is $0.94 \%$. The simulated temperature with a mean of $-1.83^{\circ} \mathrm{C}$ (dashed line in Figure 10b) is slightly lower than the measurements (mean $=-1.78^{\circ} \mathrm{C}$ ), and the MBD is $2.8 \%$. The observed water temperatures had an opposite phase to salinity during the polynya events, and the temperature remained near the freezing point $\left(-1.8^{\circ} \mathrm{C}\right)$ during the entire winter.

[37] Salinity decreases during 20-25 January (FP2), 10-25 February (FP3), and 20-25 March are notable. During these periods, strong cyclones (not shown) moved from Siberia to the Bering Sea, which drove currents northward (also see Figures 8b-8d), bringing lower-salinity water from the south shelf and dramatically reducing the salinity in the SLIP area (see Figure 11a). The observed salinity increased by $\sim 1$ psu from January to April (Figure 10a). At the same time, the warm water from the south was also advected to the south shore of the island (Figure 11b). The magnitude and manner of the increase in salinity attributable to sea ice formation is discussed in section 3.6.

\subsection{Spatial Distribution of Ice Thickness, Wind-Ice-Water Velocity, Water Temperature, and Salinity in the SLIP}

[38] To investigate the formation mechanism of the SLIP and related oceanographic features, we examine the spatial features of the six polynyas. Figure 12 shows ice thickness distributions of the six polynyas superimposed with wind (red), ice (green), and surface ocean current (black) velocities. The polynya ice thickness is defined as less than $12 \mathrm{~cm}$ in the CIOM based on the measurements of 10-20 cm [Drucker et al., 2003]. Large polynyas occurred in FP1, CP1, FP4, and FP5, when northerly, northwesterly, or northeasterly winds prevailed; at the same time, ocean surface currents were directed downwind, less than $60^{\circ}$ (see Figure 10a). During FP2, the surface ocean currents south of St. Lawrence Island were northwestward or northeastward, against the southwestward winds, pushing sea ice toward the south shore of the island. During FP3, although the prevailing winds were southwestward, the ocean surface currents south of the island were prevailingly northwestward, unfavorable for the development of the SLIP. Again, the angles between the ocean current and wind were mostly larger than $60^{\circ}$. Furthermore, the strong northwestward currents advected the low-salinity water from the south toward the island, causing a decrease in salinity (Figures 10a and 11a). Note that although the FP2 and FP3 were not reproduced well using the $12 \mathrm{~cm}$ thickness criterion, Figures $12 \mathrm{c}$ and $12 \mathrm{~d}$ show lower ice in the SLIP area compared with the surrounding ice cover. In other words, the model reproduces thin ice in the SLIP area during FP2 and FP3, although not sufficiently low $(<12 \mathrm{~cm})$ to be defined as a polynya.

Table 2. Multiple-Variable, Linear Regression Models Using Modeled Data From January to April 1999 and Their Statistics ${ }^{\mathrm{a}}$

\begin{tabular}{|c|c|c|c|c|c|c|c|c|c|c|c|}
\hline Model & Parameters & Intercept & WWA & $\tau_{x_{-} \text {water }}$ & $\tau_{y_{-} \text {water }}$ & $\tau_{x \_ \text {wind }}$ & $\tau_{y_{-} \text {wind }}$ & $\begin{array}{c}\text { Residual } \\
\text { Standard } \\
\text { Error }\end{array}$ & $R^{2}$ & $\begin{array}{c}\text { Adjusted } \\
R^{2} \\
\end{array}$ & F Statistics \\
\hline \multirow[t]{4}{*}{1} & Coefficient & 0.505 & -0.002 & 0.128 & -0.328 & -0.772 & -1.173 & 0.357 & 0.230 & 0.143 & 2.633 \\
\hline & $T$ value & 4.114 & -1.652 & 0.352 & -0.799 & -0.727 & -1.665 & & & & \\
\hline & Probability & 0.000 & 0.106 & 0.727 & 0.429 & 0.471 & 0.103 & & & & 0.036 \\
\hline & Standard error & 0.123 & 0.001 & 0.363 & 0.411 & 1.062 & 0.705 & & & & \\
\hline \multirow[t]{4}{*}{2} & Coefficient & 0.542 & -0.002 & & -0.324 & & -1.103 & 0.351 & 0.221 & 0.170 & 4.352 \\
\hline & $T$ value & 5.031 & -1.818 & & -1.547 & & -2.145 & & & & \\
\hline & Probability & 0.000 & 0.076 & & 0.129 & & 0.037 & & & & 0.009 \\
\hline & Standard error & 0.108 & 0.001 & & 0.209 & & 0.514 & & & & \\
\hline \multirow[t]{4}{*}{3} & Coefficient & 0.355 & & 0.080 & -0.581 & -1.011 & -1.087 & 0.364 & 0.183 & 0.110 & 2.513 \\
\hline & $T$ value & 4.229 & & 0.218 & -1.494 & -0.943 & -1.518 & & & & \\
\hline & Probability & 0.000 & & 0.829 & 0.142 & 0.351 & 0.136 & & & & 0.054 \\
\hline & Standard error & 0.084 & & 0.369 & 0.389 & 1.072 & 0.716 & & & & \\
\hline
\end{tabular}

\footnotetext{
${ }^{a}$ The smaller the standard residual error, the better the hindcast model. The higher the adjusted $R^{2}$ value, the better the correlation between the hindcast
} model and the observed ice time series. The larger the overall coefficient (see F statistics), the better the regression model. 


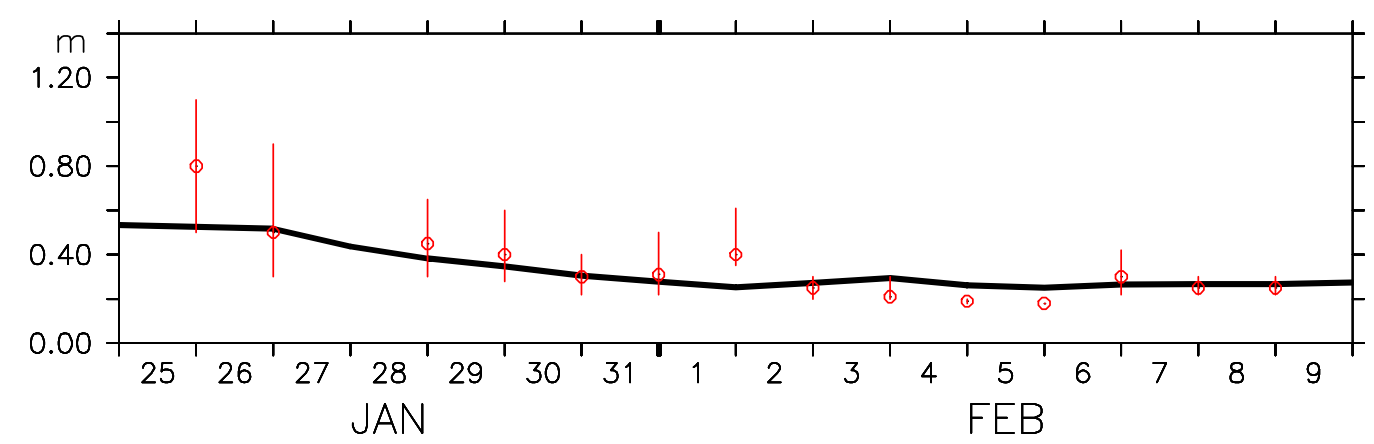

Figure 9. Sea ice thickness simulated from 26 January to 10 February 1999 (solid line). Measurements using 5-min Upward Looking Sonar samples (ULS-15, located at $170.33^{\circ} \mathrm{W}, 62.93^{\circ} \mathrm{N}$, shown in Figure 7) were used to derive the mean ice thickness (open circles) with the vertical lines showing the range of the uncertainties (reproduced from the work by Drucker et al. [2003]).

[39] While a SLIP occurs, the following features are observed in the SLIP region and the region to the north of the island. High salinity and low temperature are usually observed in the ocean off the south shore relative to the north shore. The wind blows sea ice away to form a polynya, and thin ice is observed in the ocean off the south shore. Thick ice occurs in the ocean off the north shore since the wind piles up sea ice toward the north shore. Also, because of the Ekman drift of the surface current, an upwelling is observed off the south shore and a downwelling occurs off the north shore. We examined all six of these scenarios and came to these conclusions.

[40] Below we examine the hydrographic response to the occurrence of FP4. The conclusions can be applied to all the SLIPs, although the anomalous ambient ocean current and its advection of remote low-salinity, warm water can modify some local features caused by the SLIP. These unique features can have significant impacts on local ecosystems such as nutrient transport and benthos [Grebmeier and Cooper, 1995].

[41] During FP4, northerly winds blew away sea ice in the ocean off the south shore and piled up sea ice off the north shore ( $\sim 60 \mathrm{~cm}$ thick) (Figure $13 \mathrm{a}$, along $\left.171^{\circ} \mathrm{W}\right)$. Because of supercooling, more sea ice formed in the south shore region compared with the north shore region, where brine injection caused dense water formation [Wang et al., 2003, 2009]. Thus, salinity was higher off the south shore relative to that off the north shore (Figure 13b). Because of deep convection and dense water formation, the temperature was colder off the south shore than off the north shore (Figure 13c). In the ocean off the south (north) shore, upwelling (downwelling) occurred (Figures 13d and 13e) because of the wind-driven
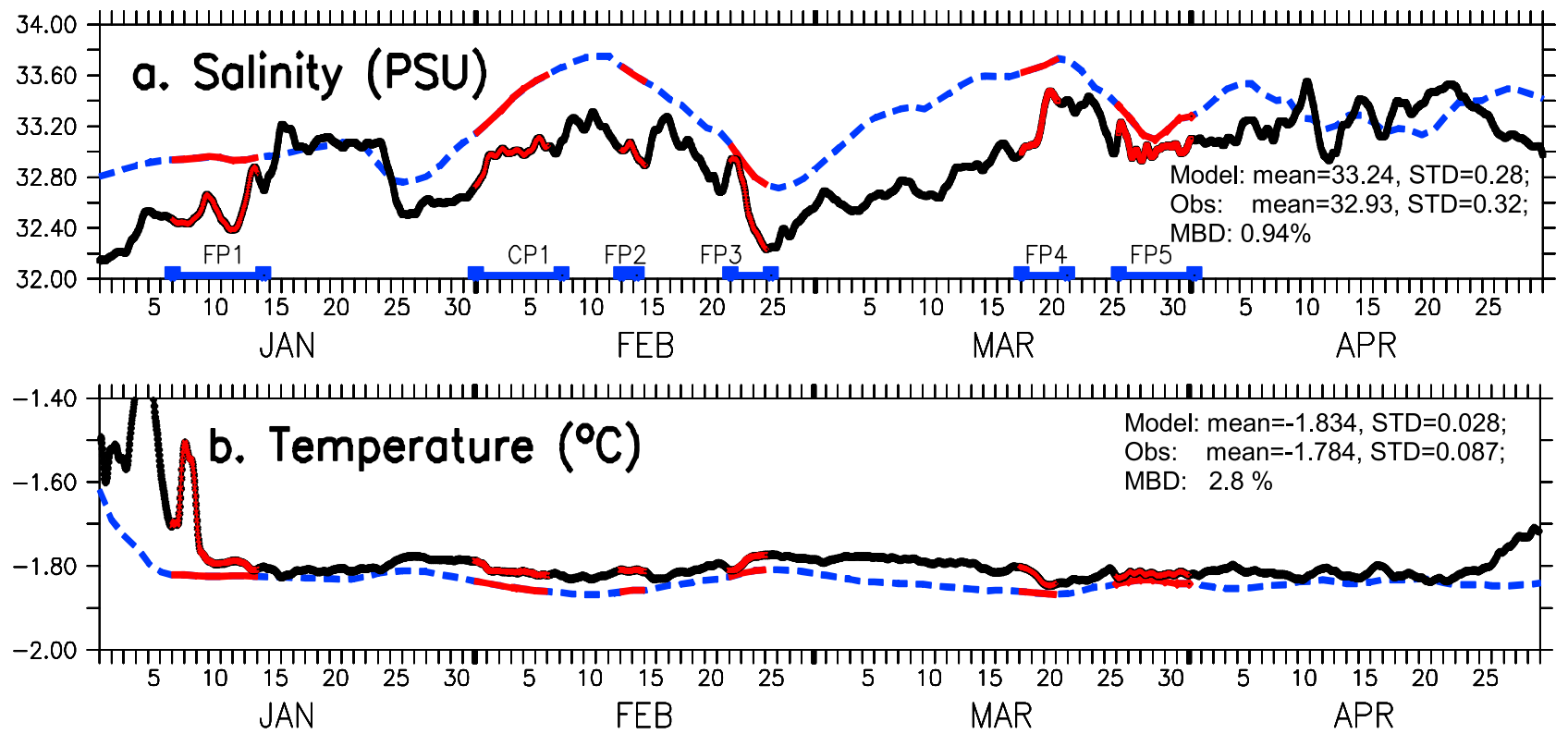

Figure 10. Averaged temperature and salinity at near bottom $(\sim 30 \mathrm{~m})$ south of St. Lawrence Island: The black solid lines denote the mooring data (the mooring stations are described in Figure 8), the blue dashed lines denote the model result, and the reported polynyas events [Drucker et al., 2003] are highlighted in red. Standard deviation (STD) and mean bias deviation (MBD) are also provided. 


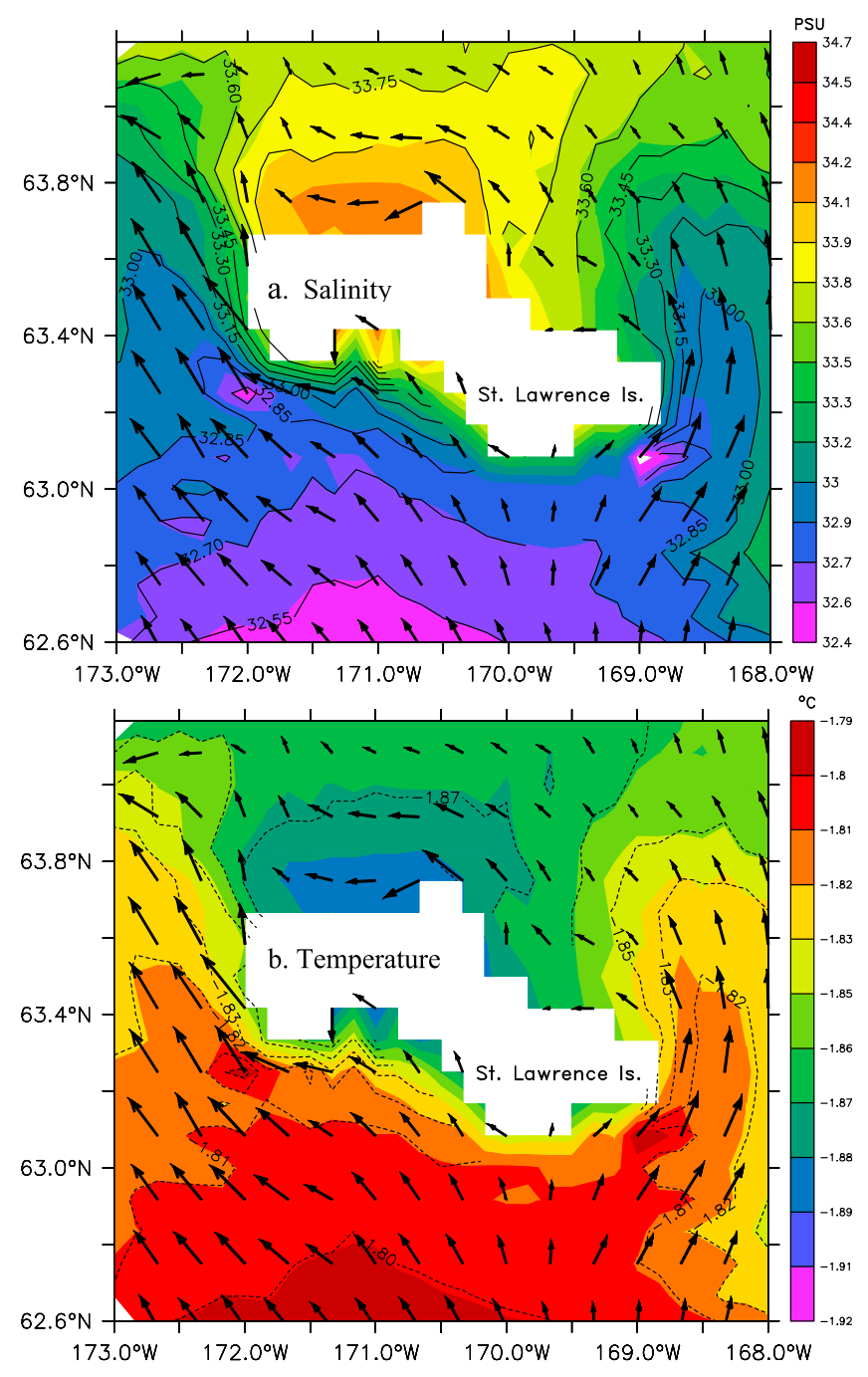

Figure 11. (a) Simulated surface salinity field (in psu) and (b) temperature field, superimposed by the surface ocean current during FP3.

Ekman drift [Wang et al., 2009]. In summary, wind is the major mechanism for oceanic upwelling during the SLIP formation under supercooling conditions. Oceanographic responses to the SLIP are significant for defining ecosystem regimes, in particular between the ocean regions off the south and north shores [Grebmeier and Cooper, 1995].

\subsection{Potential Sea Ice Production and Its Contribution to Salinity}

\subsubsection{Potential Sea Ice Production}

[42] Potential sea ice production (PSIP), which is defined as the total sea ice production in terms of volume (melted ice is excluded) per day in the Bering Sea (units are in $\mathrm{km}^{3} \mathrm{~d}^{-1}$ ), is examined. The distribution of accumulated (from November 1998 to May 1999) sea ice thickness, as simulated by the CIOM, shows that high production regions were located south of the Siberian coast, the Seward coast, and south of St. Lawrence Island (Figure 14), where polynya events occurred frequently [Niebauer et al., 1999]. The maximum cumulative thickness could reach $22 \mathrm{~m}$ in the Gulf of Anadyr. South of St. Lawrence Island, the cumulative thickness was $14 \mathrm{~m}$. These ice factories, consistent with the frequently measured polynyas [Niebauer et al., 1999], continuously produced sea ice throughout the winter, while northerly winds and ocean currents drove the locally produced sea ice offshore, along with thermal melting.

[43] The daily PSIP rate on the Bering Shelf increased from November 1998 to January 1999 and reached a peak of $59 \mathrm{~km}^{3} \mathrm{~d}^{-1}$ in early February; then gradually decreased with fluctuations until May 1999 (solid line in Figure 15). The daily PSIP rate in the SLIP area shows a similar pattern (dashed line in Figure 15) that is due to the same atmospheric forcing, except that sea ice initially formed $\sim 1.5$ months later because of its location in the south. The simulated SLIP area is $10,240 \mathrm{~km}^{2}$, which is $\sim 1.0 \%$ of the total shelf area of $971,747 \mathrm{~km}^{2}(<200 \mathrm{~m})$. Nevertheless, the maximum daily production rate of $0.8-0.9 \mathrm{~km}^{3} \mathrm{~d}^{-1}$ accounts for $2.4 \%$ of the total daily production rate in the whole Bering Shelf. This indicates that the SLIP is very productive.

\subsubsection{Sea Ice Contribution to Salinity Change}

[44] Salinity change is defined as salinity minus the reference salinity (32.4 psu) on 1 November 1998 $\left(S_{t}-S_{1 \text { November }}\right)$, since sea ice usually forms in early November. Salinity changes (Figure 16a, black solid line) averaged over the Bering Shelf $(<200 \mathrm{~m})$ increased from 0 in November 1998 to 1.15 psu in March 1999, fluctuated from March to April, and then continually decreased until October.

[45] Salinity changes contributed by sea ice are derived from:

$$
\frac{\iint_{\text {Domain }} \Delta h_{\text {ice }} \times\left(S_{\text {water }}-S_{\text {ice }}\right) \mathrm{d} x \mathrm{~d} y}{\text { Volume }_{\text {water }}}
$$

where $\Delta h_{\text {ice }}$ is the sea ice thickness change at each grid cell, $S_{\text {water }}$ is the salinity of water at each grid cell, $S_{\text {ice }}$ is the salinity of ice (15 PSU is set here), and Volume water $_{\text {is the }}$ volume of water of the computed domain. The daily salinity change by sea ice formation (Figure 16a, green dotted line) increased from November to the end of January and then decreased with fluctuations until May. The phase was consistent with that of the salinity change for the whole Bering Shelf. This indicates that sea ice is a major contributor to salinity change.

[46] The accumulated running sum of salinity (Figure 16a, red dashed line) contributed by sea ice increased to the maximum of $\sim 0.64 \mathrm{psu}$ in May 1999 because of continuous freezing (brine injection), which accounts for $63 \%$ of all salinity changes (averaged over November-March) in the Bering Shelf. Note that sea ice melting, which produces negative salinity, is not included here.

[47] Salinity changes in the SLIP area were also examined. The changes range from -0.4 to $1.05 \mathrm{psu}$ with large fluctuations (Figure 16b, black solid line) in such a small domain. The accumulated sum of salinity (Figure 16b, red dashed line) contributed by sea ice increased to a maximum of $2.0 \mathrm{psu}$ at the end of April 1999, which is more than 


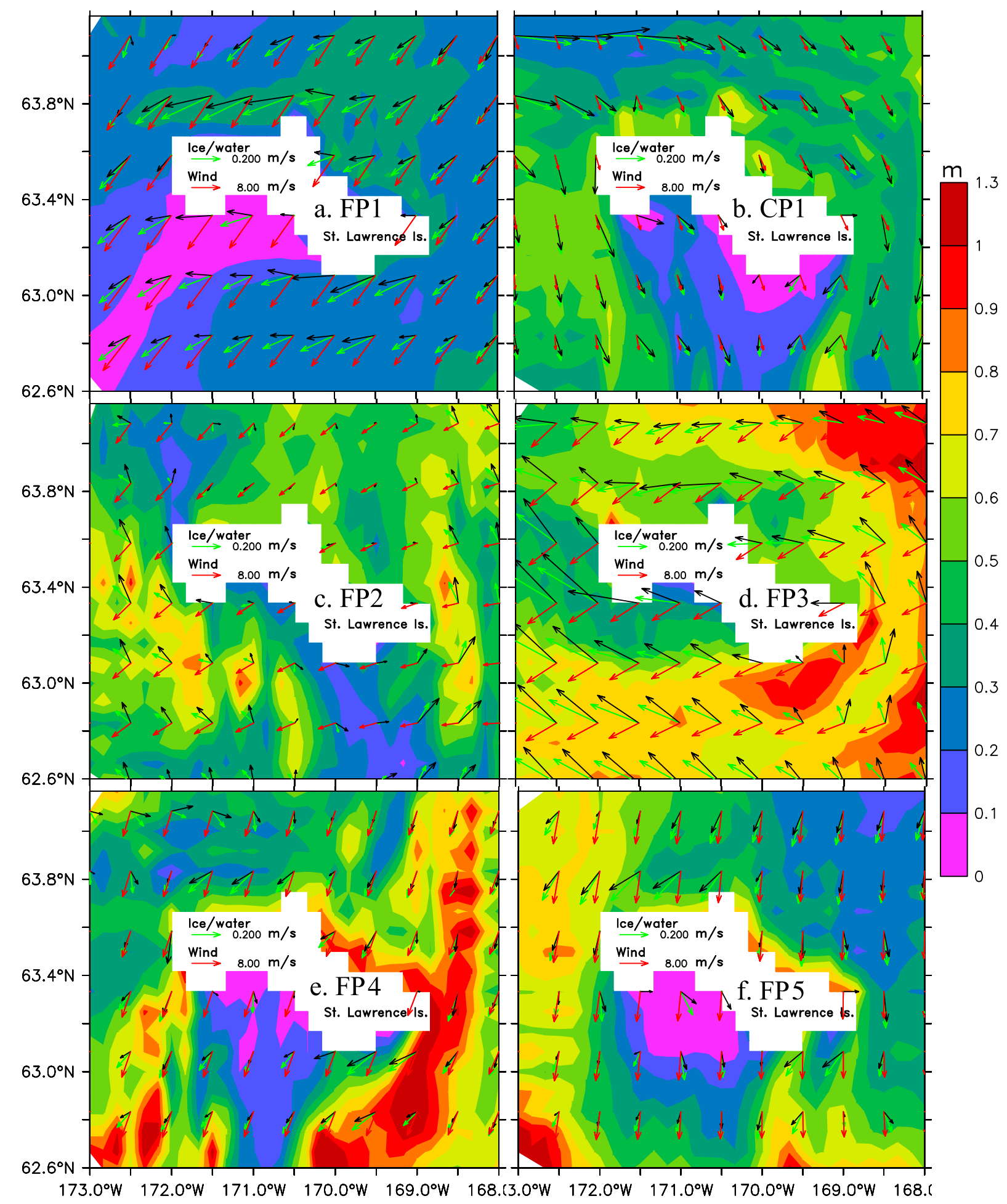

Figure 12. Simulated ice thickness (in meters), superimposed by the NCEP wind vectors (red), ice velocity (green), and surface water current (black) during (a) FP1, (b) CP1, (c) FP2, (d) FP3, (e) FP4, and (f) FP5. 


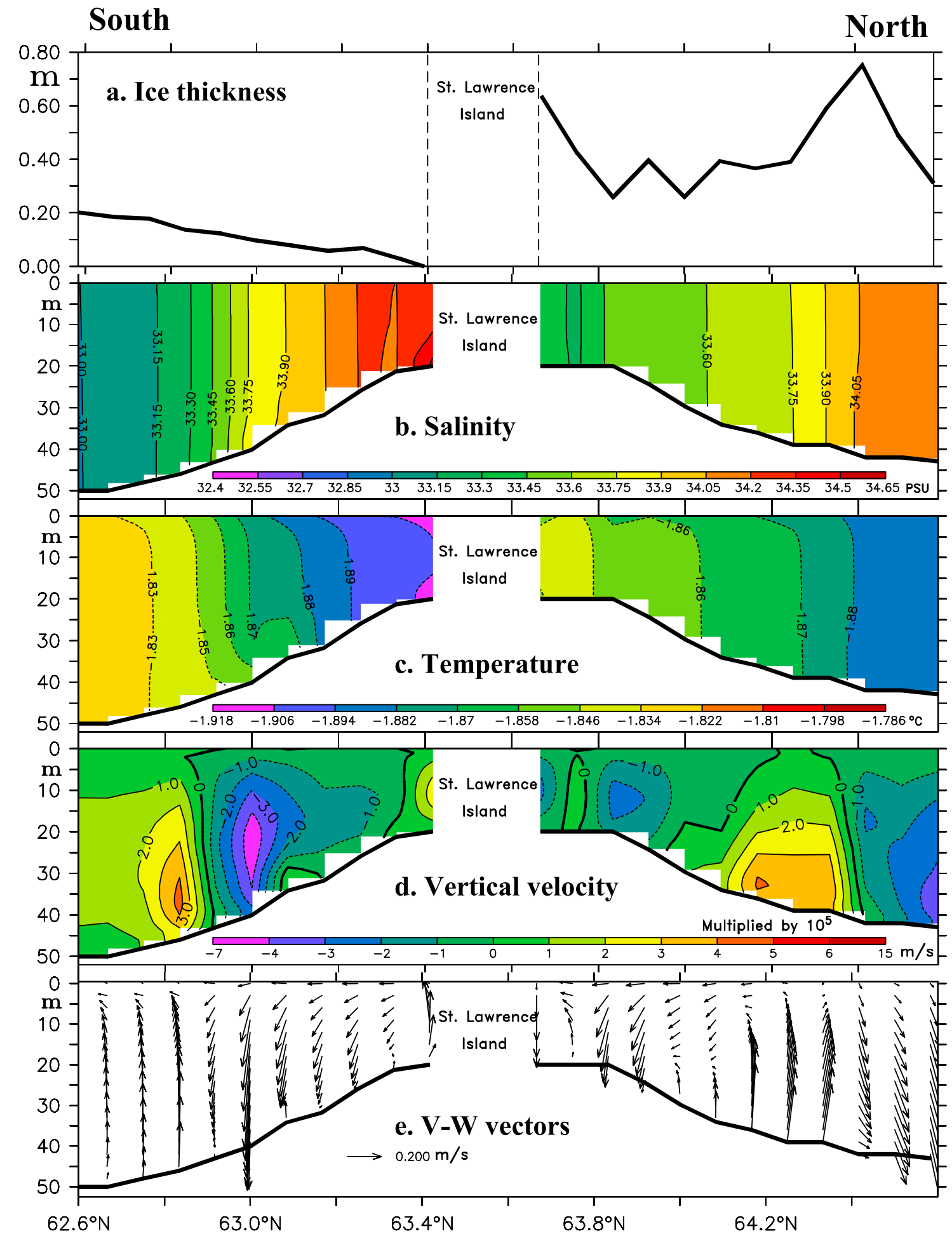

Figure 13. Simulation of the $171^{\circ} \mathrm{W}$ line (S-N) transects during the FP4 period of (a) ice thickness, (b) salinity, (c) temperature, (d) vertical velocity $\left(10^{5} \mathrm{~m} \mathrm{~s}^{-1}\right.$ ), and (e) $\mathbf{v}-w$ vectors (with $\mathbf{w}$ being multiplied by a factor of $10^{5}$ ). 


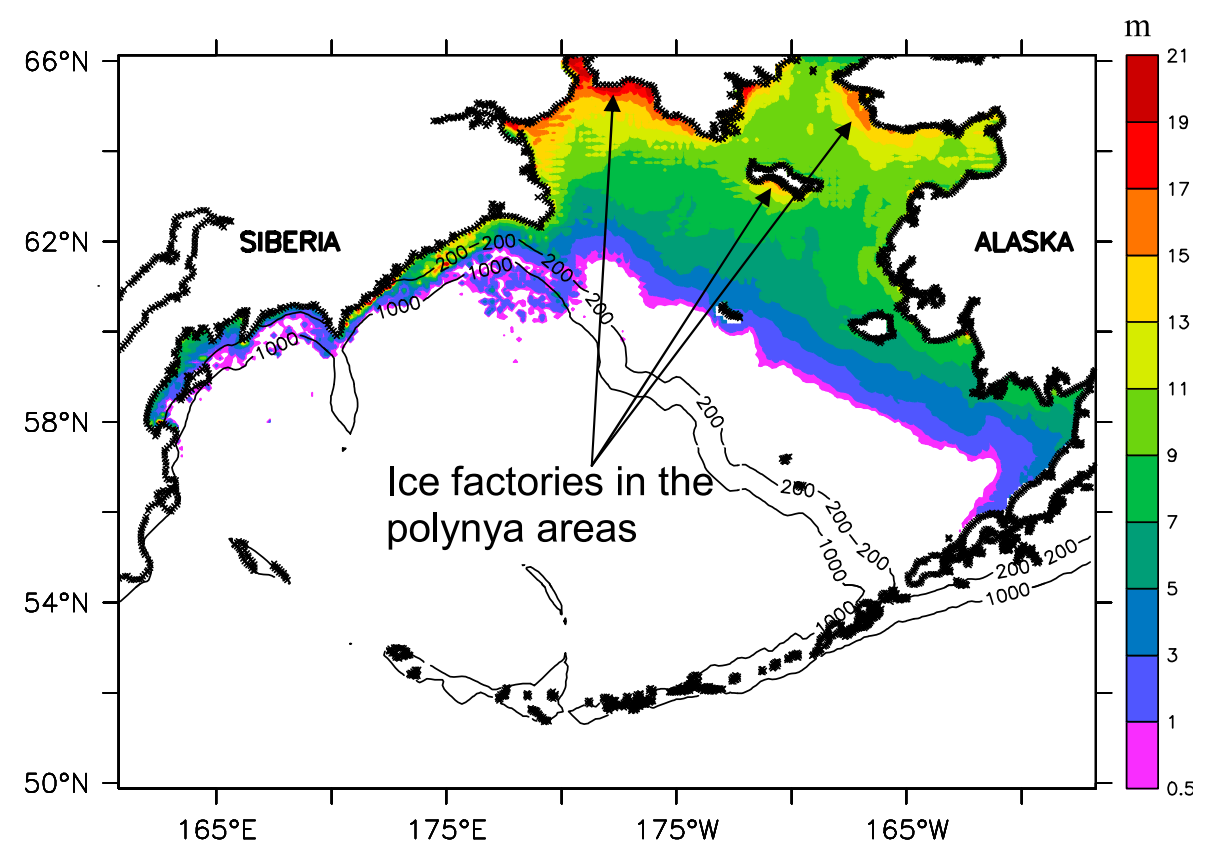

Figure 14. Simulated distributions of potential sea ice thickness $(\mathrm{m})$ accumulated from 1 November 1998 to 30 June 1999.

double (230\%) the salinity changes in the entire SLIP area. This indicates that more than half of the salinity that is due to sea ice formation was diluted because of ice melting and was advected out of the SLIP area. Therefore, ice formation in the SLIP region significantly influences not only the local salinity, but also the salinity distribution in the surrounding area.

\section{Conclusions and Discussion}

[48] Bering Sea ice and polynya development in the winter of 1998-1999 was investigated using the CIOM and in situ measurements. The seasonal cycle of sea ice cover was reasonably reproduced by the model. The simulated sea ice coverage in the whole Bering Sea agrees well with observations, with $11 \%$ error. The in-depth investigation of SLIP and its mechanisms were conducted using the CIOM along with the mooring's time series. The model-data comparison was quantitatively measured by the MBD. Based on the above investigation, the following conclusions can be drawn:

[49] 1. The offshore wind is necessary, but is not sufficient on its own to trigger the development of the SLIP. The polynya can be triggered when winds and surface currents are in a similar offshore wind direction. When the angle between the wind velocity and surface current is smaller than $60^{\circ}$, polynyas are most likely triggered, indicating the important role on the SLIP formation contributed by the surface ocean current.

[50] 2. The simulated sea ice velocity on the Bering Shelf drifts with the wind in a clockwise inclination of $32.7^{\circ}$, and water velocity is directed to the right of the ice velocity by $17.7^{\circ}$. Because of the year-round northward flow on the Bering Shelf, the classic Ekman drift theory that surface water moves at $45^{\circ}$ to the right of the wind direction is modified to $\sim 50.4^{\circ}$ for an ice-covered shelf.
[51] 3. The most productive areas, i.e., the ice factories, are located to the south of the Siberian coast, the Seward coast, and St. Lawrence Island. The simulated yearly sea ice production in the SLIP area is about $95.7 \mathrm{~km}^{3}$, which accounts for $2.8 \%$ of the $3393 \mathrm{~km}^{3}$ in the entire Bering Sea. Since the SLIP accounts for $1 \%$ only of the Bering Shelf, the SLIP's production rate is 2.8 times that of the whole shelf.

[52] 4. Salt injection by local sea ice formation is the leading factor controlling winter salinity changes in the Bering Shelf, contributing $63 \%$ of the total change, whereas the SLIP can contribute more than twice $(230 \%)$ the local salinity change. The local change of salinity in the SLIP region can affect the surrounding salinity distribution because of horizontal advection by ocean currents.

[53] The model failed to reproduce two small polynyas, FP2 and FP3, using the thickness criterion of $12 \mathrm{~cm}$ because the surface water velocity was not in the offshore wind direction. The surface current was against the prevailing northeasterly winds, leading to unfavorable conditions for

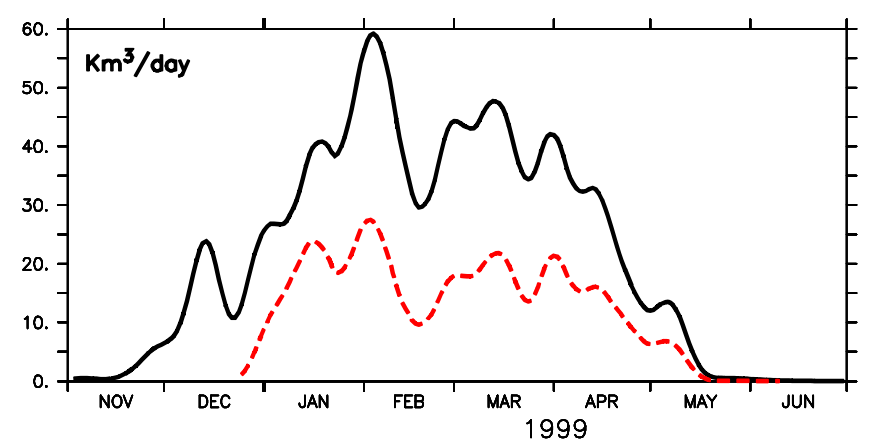

Figure 15. Simulated daily potential sea ice production over the Bering Shelf (solid line) and in the SLIP area (dashed line; dashed values have been multiplied by 20 for comparison). 

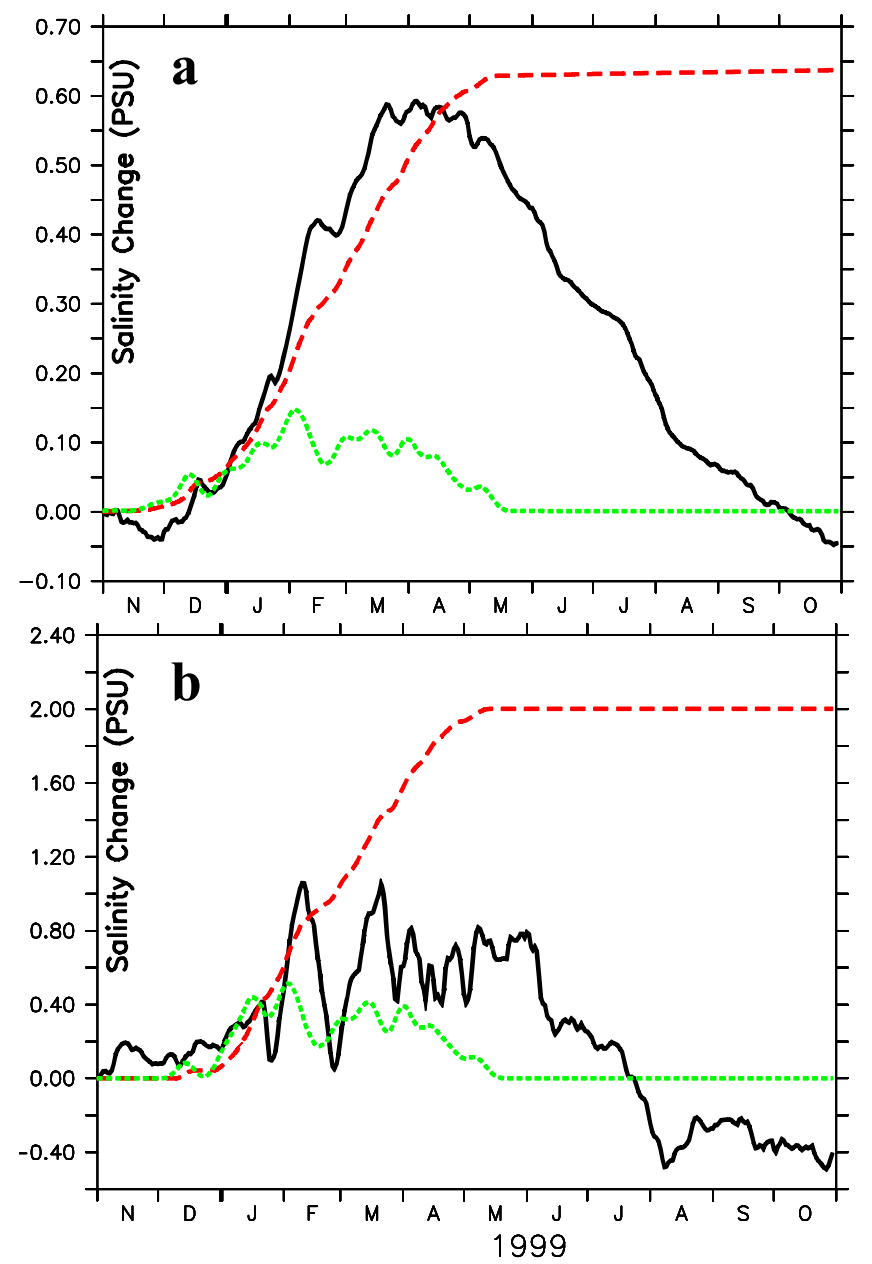

Figure 16. Salinity changes are defined as salinities minus the salinity (32.4) on 1 November 1998. The lack solid line denotes the domain-averaged total changes. The green dotted line denotes salinity (daily) contributed by sea ice that is multiplied by 20 for better comparison. The red dashed line denotes accumulated salinity (running sum) contributed by sea ice. (a) On the whole Bering Shelf and (b) in the SLIP area.

the development of the SLIP. During these periods, the WWA was larger than $60^{\circ}$. The northwestward ocean current advected not only sea ice from the south toward the south shore of the island, which increased the ice thickness there, but also advected warm, low-salinity water toward the south shore of the island. It is noted that although the model did not capture these two small polynya events (FP2 and FP3), it indeed reproduced the small thin ice area off the south shore.

[54] Wind duration is responsible for SLIP development if the WWA is less than $60^{\circ}$ (Table 2). However, when the WWA is greater than $60^{\circ}$, i.e., the surface ocean current flows against the prevailing northerly wind, the SLIP may not occur.

\section{Appendix A: The Thermodynamic Equations}

[55] The coupling of dynamic equations of open water was discussed by Wang et al. [2002, 2005]. Here, only the thermodynamic equations of sea ice are described. The thermodynamic model assumes that the sea ice bottom temperature is at the freezing point. When the air temperature is greater than the freezing point, the sea ice surface temperature is set to the freezing point; and the sea surface temperature is set to no lower than the freezing point when water is freezing.

[56] Total heat flux $F$ includes the sensible heat $\left(F_{S}\right)$, the latent heat $\left(F_{L}\right)$, the long-wave radiation $\left(F_{\mathrm{LW}}\right)$, and the shortwave radiation $\left(F_{\mathrm{SW}}\right)$, that is, $F=F_{\mathrm{SW}}+F_{\mathrm{LW}}+F_{S}+F_{L}$ :

$$
\begin{aligned}
& F_{\mathrm{SW}}=\left(1-\alpha_{i}\right) I_{0} \\
& F_{\mathrm{LW}}=-\sigma\left(0.746+6.6 \times 10^{-5} P_{a}\right) T_{a}^{4}+\varepsilon_{i} \sigma T_{i}^{4} \\
& F_{S}=\rho_{a} C_{p a} C_{S}|V|\left(T_{i}-T_{a}\right) \\
& F_{L}=L_{e} \rho_{a} C_{e}|V|\left(Q_{i}-Q_{a}\right)
\end{aligned}
$$

where $I_{0}$ is the incoming solar short-wave radiation, $\alpha_{i} I_{0}$ is the reflected short-wave radiation, and the albedo of ice surface $\alpha_{i}$ is 0.6 . The albedo of the water surface is set to 0.28 , which is higher than the usual value of 0.1 [ Gill, 1982, p. 7]. This is due to the bias of the NCEP reanalysis data that overestimates short-wave radiation in the Bering Sea [Ladd and Bond, 2002]. The incoming long-wave radiation from the atmosphere and clouds is $-\sigma(0.746+6.6 \times$ $\left.10^{-5} P_{a}\right) T_{a}^{4}$, where $\sigma=5.67 \times 10^{-8} \mathrm{~W}\left(\mathrm{~m}^{2} \mathrm{~K}\right)^{-1}$ is the Stefan-Boltzmann constant, $P_{a}$ is the vapor pressure, and $T_{a}$ is the air temperature. Outgoing long-wave radiation is $\varepsilon_{i} \sigma T_{i}^{4}$, where $T_{i}$ is the sea ice surface temperature and $\varepsilon_{i}=$ 0.97 is the emissivity of the ice surface. $\rho_{a}=1.27 \mathrm{~kg} \mathrm{~m}^{-3}$ is reference air density, $C_{p a}=1005 \mathrm{~J}(\mathrm{~kg} \mathrm{~K})^{-1}$ is the specific heat of air, $C_{s}=1.1 \times 10^{-3}$ is the sensible heat bulk coefficient, and $V$ is the wind speed. $L_{e}=3.347 \times 10^{5} \mathrm{~J} \mathrm{~kg}^{-1}$ is the latent heat of fusion, $C_{e}=1.75 \times 10^{-3} \mathrm{~J}(\mathrm{~kg} \mathrm{~K})^{-1}$ is latent heat bulk coefficient, $Q_{i}$ is the specific humidity at the sea surface, and $Q_{a}$ is the specific humidity of air.

[57] Inside the ice, heat conduction flux $F_{c}$ exists because of a nonuniform temperature distribution: $F_{c}=k \frac{\partial T}{\partial z}=\frac{k\left(T_{b}-T_{i}\right)}{h_{i}}$, where $k=2.04 \mathrm{~J}(\mathrm{~kg} \mathrm{~K})^{-1}$ is the ice thermal conductivity, $T_{b}$ is the ice bottom temperature, $T_{i}$ is the sea ice surface temperature, and $h_{i}$ is the sea ice thickness.

[58] The sea ice surface temperature $T_{i}$ is an unknown and is calculated using the following heat equilibrium equation at the air-ice interfaces:

$$
\frac{k\left(T_{b}-T_{i}\right)}{h_{i}}=\left(F_{S}+F_{L}\right)_{T_{i}}+F_{\mathrm{LW}}+F_{\mathrm{SW}} .
$$

[59] Solving this equation, we can obtain $T_{i}$, and, in turn, we can then calculate the heat flux $F_{c}$ (heat transferred from ice to air): $F_{c}-C_{p i} \Delta T_{i}$, which transfers heat from water to ice, where $C_{p i}=2093 \mathrm{~J}(\mathrm{~kg} \mathrm{~K})^{-1}$ is the specific heat of ice and $\Delta T_{i}$ is the sea ice temperature change.

[60] When ice melts, the heat is transferred from air to ice and also from water to ice. The bottom-lateral melting that is due to the heat flux from the water to the ice was added to this model [Wang et al., 2009] following Maykut and McPhee [1995], McPhee [1992], and Ohshima and Nihashi [2005]:

$$
F_{w i}=\rho_{w} C_{p w} C_{h} u_{*}\left(T_{w}-T_{b}\right)
$$


where $\rho_{w}$ is the water density, $C_{p w}=3980 \mathrm{~J} \mathrm{~kg}^{-1}$ is the specific heat for seawater near freezing, $C_{h}=0.006$ is the heat transfer coefficient, $u^{*}$ is the turbulent friction speed, $T_{w}$ is the surface water temperature, and $T_{b}$ is the bottom ice temperature, which is set to be the freezing point.

[61] Acknowledgments. We appreciate support from NOAA RUSALCA (Russian-American Long-term Census of the Arctic) International Polar Year modeling project. Thanks also go to Seth Danielson for providing the data and comments on the first draft, Xuezhi Bai for conducting the regression model simulations, and Cathy Darnell and Ray Assel for editing this manuscript. This is GLERL contribution 1602.

\section{References}

Blumberg, A. F., and G. L. Mellor (1987), A description of 3-D coastal ocean circulation model, in 3Three-Dimensional Coastal Ocean Models, Coastal Estuarine Sci. Ser., vol. 4, edited by N. S. Heaps, pp. 1-16, AGU, Washington, D. C.

Cavalieri, D. J., and S. Martin (1994), The contribution of Alaskan, Siberian, and Canadian coastal polynyas to the cold halocline layer of the Arctic Ocean, J. Geophys. Res., 99(C9), 18,343-18,362, doi:10.1029/ 94JC01169.

Danielson, S., K. Aagaard, T. Weingartner, S. Martin, P. Winsor, G. Gawarkiewicz, and D. Quadfasel (2006), The St. Lawrence polynya and the Bering Shelf circulation: New observations and a model comparison, J. Geophys. Res., 111, C09023, doi:10.1029/2005JC003268.

Drucker, R., S. Martin, and R. Moritz (2003), Observations of ice thickness and frazil ice in the St. Lawrence Island polynya from satellite imagery, upward looking sonar and salinity/temperature moorings, J. Geophys. Res., 108(C5), 3149, doi:10.1029/2001JC001213.

Gill, A. E. (1982), Atmosphere-ocean Dynamics, Int.l Geophys. Ser., vol. 30, 662 pp., Academic, San Diego, Calif.

Grebmeier, J. M., and L. W. Cooper (1995), Influence of the St. Lawrence Island polynya upon the Bering Sea benthos, J. Geophys. Res., 100(C3), 4439-4460, doi:10.1029/94JC02198.

Hibler, W. D., III (1979), A dynamic thermodynamic sea ice model, J. Phys. Oceanogr., 9, 815-846, doi:10.1175/1520-0485(1979)009<0815: ADTSIM $>2.0 . \mathrm{CO} ; 2$.

Hibler, W. D., III (1980), Modeling a variable thickness sea ice cover, Mon. Weather Rev., 108, 1943-1973, doi:10.1175/1520-0493(1980)108<1943: MAVTSI $>2.0 . \mathrm{CO} ; 2$.

$\mathrm{Hu}, \mathrm{H}$., and J. Wang (2010), Modeling effects of tidal and wave mixing on circulation and thermohaline structures in the Bering Sea: Process studies, J. Geophys. Res., 115, C01006, doi:10.1029/2008JC005175.

Ladd, C., and N. A. Bond (2002), Evaluation of NCEP/NCAR reanalysis in the NE Pacific and the Bering Sea, J. Geophys. Res., 107(C10), 3158, doi:10.1029/2001JC001157.

Long, Z., W. Perrie, C. L. Tang, E. Dunlap, and J. Wang (2011), Simulated interannual variations of fresh water content and sea surface height in the Beaufort Sea, J. Clim., doi:10.1175/2011KCI14121.1, in press.

Lynch, M., F. Glueck, W. L. Chapman, D. A. Bailey, and J. E. Walsh (1997), Satellite observation and climate system model simulation of the St. Lawrence Island polynya, Tellus A, 49, 277-297.

Maykut, G. A., and M. G. McPhee (1995), Solar heating of the Arctic mixed layer, J. Geophys. Res., 100(C12), 24,691-24,703, doi:10.1029/ 95JC02554

McPhee, M. G. (1992), Turbulent heat flux in the upper ocean under sea ice, J. Geophys. Res., 97(C4), 5365-5379, doi:10.1029/92JC00239.

Mellor, G. L. (2004), User's Guide for a Three-Dimensional, Primitive Equation, Numerical Ocean Model, 56 pp., Program in Atmos. and Oceanic Sci., Princeton Univ. Press., Princeton, N. J.

Mellor, G. L., and L. Kantha (1989), An ice-ocean coupled model, J. Geophys. Res., 94(C8), 10,937-10,954, doi:10.1029/JC094iC08p10937.

Muench, R. D., and K. Ahlnas (1976), Ice movement and distribution in the Bering Sea from March to June 1974, J. Geophys. Res., 81(24), 4467-4476, doi:10.1029/JC081i024p04467.

Niebauer, H. J. (1998), Variability in Bering Sea ice cover as affected by a regime shift in the North Pacific in the period 1947-1996, J. Geophys. Res., 103(C12), 27,717-27,737, doi:10.1029/98JC02499.

Niebauer, H. J., N. A. Bond, and L. P. Yakunin (1999), An update on the climatology and sea ice of the Bering Sea, in Dynamics of the Bering Sea, edited by T. R. Loughlin and K. Ohtani, pp. 29-60, North Pac. Mar. Sci. Organ., Univ. of Alaska Fairbanks, Fairbanks, Alaska.

Ohshima, K. I., and S. Nihashi (2005), A simple ice-ocean coupled model for the Antarctic ice melt season, J. Phys. Oceanogr., 35, 188-201, doi:10.1175/JPO-2675.1.
Pease, C. H. (1980), Eastern Bering Sea ice processes, Mon. Weather Rev., 108, 2015-2023, doi:10.1175/1520-0493(1980)108<2015:EBSIP $>2.0$. $\mathrm{CO} ; 2$.

Pedlosky, J. (1987), Geophysical Fluid Dynamics, 2nd ed., 710 pp., Springer, New York, doi:10.1007/978-1-4612-4650-3.

Shapiro, L. H., and J. J. Burns (1975), Satellite observations of sea ice movement in the Bering Strait region, in Climate of the Arctic, edited by G. Weller and S. A. Bowling, pp. 379-386, Geophys. Inst., Univ. of Alaska Fairbanks, Fairbanks, Alaska.

Steele, M., R. Morley, and W. Ermold (2001), PHC: A global ocean hydrograph with a high-quality Arctic Ocean, J. Clim., 14, 2079-2087, doi: 10.1175/1520-0442(2001)014<2079:PAGOHW >2.0.CO;2.

Tang, C. L. (2008), A coupled multi-category sea ice model and POM for Baffin Bay and the Labrador Sea, Chin. J. Polar Sci., 19(2), 149-158.

Thorndike, A. S., and R. Colony (1982), Sea ice motion in response to the geostrophic winds, J. Geophys. Res., 87(C8), 5845-5852, doi:10.1029/ JC087iC08p05845.

Thorndike, A. S., D. A. Rothrock, G. A. Maykut, and R. Colony (1975), The thickness distribution of sea ice, J. Geophys. Res., 80(33), 4501-4513, doi:10.1029/JC080i033p04501.

Wang, J., L. A. Mysak, and R. G. Ingram (1994), A numerical simulation of sea-ice cover in Hudson Bay, J. Phys. Oceanogr., 24(12), 2515-2533, doi:10.1175/1520-0485(1994)024<2515:ANSOSI>2.0.CO;2.

Wang, J., R. T. Cheng, and P. C. Smith (1997), Seasonal sea-level variations in San Francisco Bay in response to atmospheric forcing, 1980, Estuarine Coastal Shelf Sci., 45, 39-52, doi:10.1006/ecss.1996.0162.

Wang, J., M. Jin, V. Patrick, J. Allen, D. Eslinger, C. N. Mooers, and T. Cooney (2001), Numerical simulation of the seasonal ocean circulation patterns and thermohaline structure of Prince William Sound, Alaska using freshwater of a line source, Fish. Oceanogr., 10, suppl. 1, 132-148, doi:10.1046/j.1054-6006.2001.00035.x.

Wang, J., Q. Liu, and M. Jin (2002), A user's guide for a coupled ice-ocean model (CIOM) in the Pan-Arctic and North Atlantic oceans, Front. Res. Syst. Global Change Tech. Rep. 02-01, Int. Arctic Res. Cent., Univ. of Alaska Fairbanks, Fairbanks, Alaska.

Wang, J., M. Ikeda, and F. Saucier (2003), A theoretical, two-layer, reduced-gravity model for descending dense water flow on continental slopes, J. Geophys. Res., 108(C5), 3161, doi:10.1029/2000JC000517.

Wang, J., B. Wu, C. Tang, J. E. Walsh, and M. Ikeda (2004), Seesaw structure of subsurface temperature anomalies between the Barents Sea and the Labrador Sea, Geophys. Res. Lett., 31, L19301, doi:10.1029/ 2004GL019981.

Wang, J., Q. Liu, M. Jin, M. Ikeda, and F. J. Saucier (2005), A coupled iceocean model in the pan-Arctic and the northern North Atlantic Ocean: Simulation of seasonal cycles, J. Oceanogr., 61, 213-233, doi:10.1007/ s10872-005-0033-3.

Wang, J., K. Mizobata, H. Hu, M. Jin, S. Zhang, W. Johnson, and K. Shimada (2008), Modeling seasonal variations of ocean and sea ice circulation in the Beaufort and Chukchi seas: A model-data fusion study, Chin. J. Polar Sci., 19(2), 168-184.

Wang, J., H. Hu, K. Mizobata, and S. Saitoh (2009), Seasonal variations of sea ice and ocean circulation in the Bering Sea: A model-data fusion study, J. Geophys. Res., 114, C02011, doi:10.1029/2008JC004727.

Watanabe, E., J. Wang, T. Sumi, and H. Hasumi (2006), Arctic dipole and its contribution to sea ice exports in the last 20th century, Geophys. Res. Lett., 33, L23703, doi:10.1029/2006GL028112.

Weeks, W. F., and G. Weller (1984), Offshore oil in the Alaskan Arctic, Science, 225, 371-378, doi:10.1126/science.225.4660.371.

Woodgate, R., T. J. Weingartner, and K. Aagaard (2005), A year in the physical oceanography of the Chukchi Sea: Moored measurements from autumn 1990-1991, Deep Sea Res., Part II, 52(24-26), 3116-3149, doi:10.1016/j.dsr2.2005.10.016.

$\mathrm{Wu}, \mathrm{B}$., J. Wang, and R. Zhang (2004), Effects of intraseasonal variations of the Arctic Oscillation on the Barents Sea, Polar Meteorol., Glaciol, $18,82-95$.

Yao, T., C. L. Tang, and I. K. Peterson (2000), Modeling the seasonal variation of sea ice in the Labrador Sea with a coupled multicategory ice model and the Princeton Ocean Model, J. Geophys. Res., 105(C1), 1153-1165, doi:10.1029/1999JC900264.

$\mathrm{H}$. Hu, Cooperative Institute for Limnology and Ecosystems Research, School of Natural Resources and Environment, University of Michigan, 4840 S. State Rd., Ann Arbor, MI 48108, USA. (hghu@umich.edu)

D.-R. Wang, Hainan Marine Development and Design Institute, 14th Fl., Zhanghang Building, 15 Longkunbei Rd., Haikou, Hainan, 570125, China.

J. Wang (corresponding author), NOAA Great Lakes Environmental Research Laboratory, 4840 S. State Rd., Ann Arbor, MI 48108, USA. (jia.wang@noaa.gov) 